\title{
Democracy, Technology, and Growth
}

\section{Citation}

Aghion, Philippe, Alberto F. Alesina, and Francesco Trebbi. 2007. "Democracy, technology, and growth." Working paper, Department of Economics, Harvard University.

\section{Permanent link}

http://nrs.harvard.edu/urn-3:HUL.InstRepos:27759624

\section{Terms of Use}

This article was downloaded from Harvard University's DASH repository, and is made available under the terms and conditions applicable to Other Posted Material, as set forth at http:// nrs.harvard.edu/urn-3:HUL.InstRepos:dash.current.terms-of-use\#LAA

\section{Share Your Story}

The Harvard community has made this article openly available.

Please share how this access benefits you. Submit a story.

Accessibility 
NBER WORKING PAPER SERIES

DEMOCRACY, TECHNOLOGY, AND GROWTH

Philippe Aghion

Alberto Alesina

Francesco Trebbi

Working Paper 13180

http://www.nber.org/papers/w13180

\author{
NATIONAL BUREAU OF ECONOMIC RESEARCH \\ 1050 Massachusetts Avenue \\ Cambridge, MA 02138 \\ June 2007
}

The authors are particularly grateful to Daron Acemoglu for his comments. We also benefitted from discussions with Matilde Bombardini, Elhanan Helpman Guido Tabellini and seminar participants at a CIAR meeting in Toronto for comments, and we thank Daron Acemoglu, Simon Johnson, Jim Robinson, and Pierre Yared for sharing their data. Andrea Asoni provided excellent research assistance. Trebbi kindly acknowledges financial support from the Initiative on Global Financial Markets. The views expressed herein are those of the author(s) and do not necessarily reflect the views of the National Bureau of Economic Research.

(C) 2007 by Philippe Aghion, Alberto Alesina, and Francesco Trebbi. All rights reserved. Short sections of text, not to exceed two paragraphs, may be quoted without explicit permission provided that full credit, including $\odot$ notice, is given to the source. 
Democracy, Technology, and Growth

Philippe Aghion, Alberto Alesina, and Francesco Trebbi

NBER Working Paper No. 13180

June 2007

JEL No. H7

\begin{abstract}
$\underline{\text { ABSTRACT }}$
We explore the question of how political institutions and particularly democracy affect economic growth. Although empirical evidence of a positive effect of democracy on economic performance in the aggregate is weak, we provide evidence that democracy influences productivity growth in different sectors differently and that this differential effect may be one of the reasons of the ambiguity of the aggregate results. We provide evidence that political rights are conducive to growth in more advanced sectors of an economy, while they do not matter or have a negative effect on growth in sectors far away from the technological frontier. One channel of explanation goes through the beneficial effects of democracy and political rights on the freedom of entry in markets. Overall, democracies tend to have much lower entry barriers than autocracies, because political accountability reduces the protection of vested interests, and entry in turn is known to be generally more growth-enhancing in sectors that are closer to the technological frontier. We present empirical evidence that supports this entry explanation.
\end{abstract}

Philippe Aghion

Department of Economics

Harvard University

Cambridge, MA 02138

and NBER

paghion@fas.harvard.edu

Alberto Alesina

Department of Economics

Harvard University

Cambridge, MA 02138

and NBER

aalesina@harvard.edu
Francesco Trebbi

Graduate School of Business

University of Chicago

5807 South Woodlawn Avenue

Chicago, IL 60637

and NBER

ftrebbi@chicagogsb.edu 


\section{Introduction}

There are two main open questions in the debate on the relationship between economic development and democratic institutions. One is whether or not countries become democratic only at high levels of per capita income, and the second is whether or not (or when) democracy enhances economic development, captured by per capita GDP growth.

On both questions there are disagreements amongst scholars. Most observers would agree that richer countries are democracies and therefore economic development favors transitions towards political freedom, as argued by Lipset (1959) and Barro (1999). However, Acemoglu, Johnson, Robinson, and Yared (2005) suggest that this cross-sectional evidence is not robust to controlling for factors affecting simultaneously income and political institutions. When they add country fixed effects in repeated cross-country regressions they find no effect of the level of income on democracy. Admittedly this procedure looses all the information arising from cross country comparisons, which seems crucial in this context. Huntington (1991) argues that the progress towards democratization is not linear and there are back and forth waves of democratization.

On the second question the evidence is mixed at best ${ }^{1}$. Perhaps democratic institutions increase redistributive pressures ${ }^{2}$ that may be harmful to growth, especially for middle income countries, and this is one of the reasons why Barro (1996) argues that countries cannot become democracies too "soon" in terms of their level of income per capita. However, Mulligan, Sala-i-Martin and Gil (2003) do not find much of a difference in public policies between democracy and non democracies, questioning therefore any link between form of government and economic performance ${ }^{3}$. Glaeser et al. (2004) also question the causal effects of political institutions on economic growth.

Very few studies address both questions jointly. Two exceptions are Przewroski et al. (2000) and de Mesquita et al. (2003). Persson and Tabellini (2006) use the transition from democracies to dictatorship and the concept of the accumulated stock of democratic capital, concluding that the latter is conducive to growth and consolidation of democratic institutions at the same time ${ }^{4}$. Giavazzi and Tabellini (2005) analyze

\footnotetext{
${ }^{1}$ See for instance Helliwell (1994), Barro (1996) and Papaioannou and Siourounis (2004) and the refereces cited therein.

${ }^{2}$ For some results consistent with this observation see Aghion Alesina and Trebbi (2004) and Boix (2003).

${ }^{3}$ They consider education spending, spending on pensions and welfare, trade openness amongst other variables.

${ }^{4}$ On a related topic see also Rodrik and Wacziarg (2005).
} 
the timing of economic and political liberalizations.

In this paper we will focus mostly on the second question of whether or when democracy enhances economic growth. Most of the existing papers on the subject employ aggregate data on income levels and economic growth. A first point of departure of this paper is its use of disaggregated data to shed new light on the debate. A second point of departure is the idea that political institutions, and democracy in particular, may have different effects on different sectors of the economy, possibly depending on the specific characteristics of the technology and the industry's market. Our results can be summarized in three points. First, we find that democratic institutions and political rights enhance growth of more advanced sectors, namely in sectors close to the technological frontier in the sense of Acemoglu, Aghion, and Zilibotti (2006). Second we uncover that an important channel of this effect is freedom of entry in markets. Political rights are associated with freedom of entry and the latter is especially important for sectors close to the technological frontier. In fact entry of new firms and competition are especially beneficial in spurring innovation at high levels of technological development, whereas it may discourage innovation in more backward sectors as argued by Aghion et al. (2006). Third, and this is an implication of the first two results, more advanced economies benefit more from democratic institutions and therefore the demand for democracy should increase with the level of per capita income in a country, calling into question, indirectly at least, the result by Acemoglu et al. (2005) suggesting that development does not bring about democratic institutions.

That democracy may entails both, positive and negative effects, on growth, has already been stressed for example by Acemoglu (2007). There, higher democracy tends to be good for growth because it reduces the extent to which existing oligarchies can prevent entry by potential competitors. On the other hand, democracy leads to higher tax rates in equilibrium, which in turn tends to discourage innovation everything else remaining equal. However, unlike in our analysis below, in Acemoglu (2007) the comparison between the costs and benefits of democracy does not interact with the economy's proximity to the world technological frontier.

The paper is organized as follows. Section 2 presents a model of democracy and entry which blends the entry model of Aghion, Burgess, Redding, and Zilibotti (2006), henceforth ABRZ, with the model of vested interests in Acemoglu, Aghion, and Zilibotti (2006), henceforth AAZ. Section 3 discusses the empirical 
evidence. The last section concludes.

\section{The model}

The point of the model is to show that freedom of entry is especially growth enhancing in sectors closer to the technological frontier. Freedom of entry is correlated with political rights, as we assume in the model and we show below in the empirical part. Therefore the model derives the relationship between sectorial growth and democratic institutions which we then test.

\subsection{Production and profits}

Time is discrete and all agents live for one period. One final good is produced competitively using a continuum of intermediate inputs, indexed from 0 to 1 , according to the following technology:

$$
y_{t}=\frac{1}{\alpha} \int_{0}^{1} A_{i t}^{1-\alpha} x_{i t}{ }^{\alpha} d i
$$

where $x_{i t}$ is the quantity of intermediate input produced in sector $i$ at date $t, A_{i t}$ is a productivity parameter that measures the quality of the intermediate input $i$ in producing the final good, and the parameter $\alpha \in$ $(0,1)$. The final good can be used either for consumption, or as an input in the process of production of intermediate goods, or for investments in innovation. We normalize the price of the final good to one.

In each intermediate sector $i$ only one firm (a monopolist) is active in each period, and produces intermediate input $i$ using final output as input, one for one. Since the final good sector is competitive, the intermediate monopolist $i$ sells its intermediate good to the final good sector at a price equal to its marginal cost. The first order condition for the final sector producers reads as follows:

$$
p_{i t}=\left(A_{i t} / x_{i t}\right)^{1-\alpha}
$$

Then profit maximization for intermediate-good producers yields the choice:

$$
x_{i t}=A_{i t}\left(\frac{1}{\alpha}\right)^{-\frac{1}{1-\alpha}},
$$

and the equilibrium profit:

$$
\pi_{i t}=\delta A_{i t},
$$


where $\delta \equiv\left(\frac{1}{\alpha}-1\right)\left(\frac{1}{\alpha}\right)^{-\frac{1}{1-\alpha}}$.

Substituting for $x_{i t}$ in the production function for final output, we also get:

$$
y_{t}=\zeta A_{t}
$$

where

$$
A_{t}=\int_{0}^{1} A_{i t} d i
$$

is the average productivity at date $t$ and $\zeta=\left(\frac{1}{\alpha}\right)^{1-\frac{\alpha}{1-\alpha}}$ is a constant.

\subsection{Entry and incumbent innovation}

Let $p$ denote the probability of a potential entrant appearing in any intermediate sector. In the model the government directly chooses this parameter in a way described below. This is of course a short cut that captures different policies that may favor or hinder competition and entry. There are only two types of intermediate firms: advanced firms, with productivity $A_{i t}=\bar{A}_{t}$, and backward firms with productivity $A_{i t}=\frac{1}{\gamma} \bar{A}_{t}$, and we focus on technologically advanced entry; accordingly, each potential entrant arrives with the leading-edge technology parameter $\bar{A}_{t}$, which grows by the factor $\gamma$ with certainty each period. An advanced firm can use a first-mover advantage to block entry and retain his monopoly. But if the firm is backward, then entry will occur, Bertrand competition will ensue, and the technologically dominated incumbent will be eliminated and replaced by the entrant.

A new innovation costs $c_{i t} A_{i t-1}$ and allows the innovating incumbent firm to improve productivity by factor $\gamma$. We assume $c_{i t}$ to be random and i.i.d. across intermediate sectors with support $\{0, \bar{c}\}$, with

$$
\operatorname{Pr}\left(c_{i t}=0\right)=\operatorname{Pr}\left(c_{i t}=\bar{c}\right)=\frac{1}{2}
$$

The effect of entry threat $p$ on incumbent innovation will depend on the marginal benefit $v_{i t}$ which the incumbent expects to receive from an innovation. Note that firms know their cost of innovation when they decide whether to innovate (i.e. there's no uncertainty).

Consider first an incumbent who was an advanced firm last period. If he innovates then he will remain on the frontier, and hence will be immune to entry. His profit will then be $\delta \bar{A}_{t}=\delta \gamma \bar{A}_{t-1}$. If he fails to innovate 
then with probability $p$ he will be eliminated by entry and earn zero profit, while with probability $1-p$ he will survive as the incumbent earning a profit of $\delta \bar{A}_{t-1}$. Dividing through by $\bar{A}_{t-1}$, an advanced firm with innovation cost $c_{i t}$ will innovate whenever

$$
\delta(\gamma-(1-p))=\delta(\gamma-1+p)>c_{i t} .
$$

In particular an increase in entry threat encourages this incumbent to innovate. Intuitively, a firm close to the frontier responds to increased entry threat by innovating more in order to escape the threat.

Next consider an incumbent who was a backward firm last period, and who will therefore remain behind the frontier even if he manages to innovate, since the frontier will also advance by the factor $\gamma$. For this firm, profits will be zero if entry occurs, whether he innovates or not, because he cannot catch up with the frontier. Thus it will innovate whenever:

$$
\delta(1-p)(\gamma-1)>c_{i t}
$$

where the left hand side is the profit gain from innovation that will be realized with probability $(1-p)$, the probability that no potential entrant shows up. Thus in this case innovation incentives depend negatively on the entry threat $p$. Intuitively, the firm that starts far behind the frontier is discouraged from innovating as much by an increased entry threat because he is unable to prevent the entrant from destroying the value of his innovation.

We assume that initially the entry rate $p$ is equal to zero, and that

$$
A 1: \delta(\gamma-1)<\bar{c}
$$

so that, absent any entry threat, no firm with innovation cost equal to $\bar{c}$ ever innovates.

Using these assumptions, one can determine the steady-state fraction of advanced firms conditional upon $p=0$. Following ABRZ, suppose that an advanced firm that successfully innovates at date $t$, starts out in period $t+1$ as an advanced firm. All other firms start out as backward firms. Moreover, with exogenous probability $h$, a backward firm at the end of period $t$ is replaced by a new, advanced, firm at date $t+1$. If $a_{t}$ denotes the fraction of advanced firms at $t$, then it satisfies the dynamic equation (see ABRZ):

$$
a_{t+1}=z_{A} a_{t}+h\left(1-z_{A} a_{t}\right)
$$


where

$$
z_{A}=\operatorname{Pr}(c=0)=\frac{1}{2}
$$

is the probability that an advanced firm innovates if $p=0$. Thus the steady-state fraction of advanced firms is:

$$
a^{*}=\frac{h}{1-\frac{1}{2}(1-h)}=\frac{2 h}{1+h} .
$$

\subsection{Politics and the equilibrium probability of entry}

Suppose that entry policy, $p$, is determined each period by a politician that cares about the current consumption, but may also respond to bribes. Following AAZ, we assume that the politician's pay-off is equal to $H \bar{A}_{t-1}$, where $H>0$, if she chooses the policy that maximizes current output $y_{t}$, and to $B_{t}$ otherwise, where $B_{t}$ denotes the bribe that the politician may receive from private firms to limit entry. The parameter $H$ reflects the aggregate welfare concerns of politicians, or the effectiveness of check-and-balances that the political system imposes on politicians. It is our proxy for democracy in this model and we discuss this below. To compute the equilibrium bribe incumbent firms are willing to pay to prevent moving from initial entry probability $p_{0}=0$ to $p>0$, we need to compute the equilibrium payoffs for each type of firm (advanced or backward) and for each cost realization $c_{i t}=0$ or $\bar{c}$, as a function of $p$.

Consider first an advanced firm. If this firm's innovation cost is zero, then the firm will always innovate and its post-innovation profit $\delta \gamma \bar{A}_{t}$ is independent of the entry probability. However, if the innovation cost is $\bar{c}$, this firm will lose from higher entry threat only if the threat $p$ becomes sufficiently high that condition (4) holds. Then, indeed, the firm will lose the amount

$$
\bar{A}_{t-1}[\bar{c}-\delta(\gamma-1)]
$$

which is positive by Assumption (A1). Thus the maximum bribe advanced firms would be ready to pay as a whole to prevent an increase in entry threat from zero to $p$, is given by:

$$
B_{a}(p)=\bar{A}_{t-1} a^{*} \frac{1}{2}[\bar{c}-\delta(\gamma-1)] \cdot 1_{(\delta(\gamma-1+p)>\bar{c})},
$$


where $\frac{1}{2}$ is the probability that $c_{i t}=\bar{c}$ and $1_{(\delta(\gamma-1+p)>\bar{c})}$ is equal to one whenever (4) holds and to zero otherwise. $^{5}$

Now, consider a backward firm. Such a firm will innovate if and only if $c=0$ by Assumption (A1), no matter the entry probability. And it will lose from a higher threat of entry, whether it innovates or not, just because this reduces her probability of survival. The maximum bribe backward firms will be willing to pay to prevent an increase in entry threat from zero to $p$, is equal to:

$$
B_{b}(p)=\bar{A}_{t-1}\left(1-a^{*}\right)\left[\frac{1}{2} \delta p+\frac{1}{2} \frac{\delta p}{\gamma}\right]
$$

where the first (resp. second) term in the bracket is the expected loss incurred by backward firms with low (resp. high) innovation $\operatorname{cost}^{6}$.

Altogether, incumbent firms will successfully prevent the increase in entry threat from zero to $p$ whenever $p$ is greater than $p^{*}$ such that:

$$
B\left(p^{*}\right)=B_{a}\left(p^{*}\right)+B_{b}\left(p^{*}\right)=\bar{A}_{t-1} H
$$

Given that $B(p)$ is strictly increasing in $p$, equation (6) defines the equilibrium entry probability $p^{*}$ as an increasing function of $H$.

\footnotetext{
${ }^{5}$ Indeed the firm's expected profit if the entry probability is $p$, is equal to

$$
(\delta \gamma-\bar{c}) \bar{A}_{t-1}
$$

whereas it is just

$$
\delta \bar{A}_{t-1}
$$

if the firm does not innovate. The difference between the latter and the former is just equal to

$$
(\bar{c}-\delta(\gamma-1)) \bar{A}_{t-1}
$$

${ }^{6}$ A backward firm's ex ante expected profit is:

$$
\left(\frac{1}{2} \delta(1-p)+\frac{1}{2} \delta \gamma(1-p)\right) \bar{A}_{t-1}
$$

whenever the entry probability is $p$.
} 


\subsection{Democracy, distance to frontier, and growth}

The above analysis tells us that more democracy, as measured by a higher $H$, increases the probability of entry. But this in turn, encourages innovation by advanced firms whereas it discourages innovation by backward firms (from (4) and (5) above). The overall effect on aggregate innovation and growth will then depend upon the fraction of advanced firms $a^{*}$ in the economy, which also measures the economy's proximity to the world technology frontier: for $a^{*}$ sufficiently close to one, the overall effect of entry and therefore democracy on innovation will be positive, whereas it will be negative if $a^{*}$ (i.e. $h$ ) is close to zero.

\subsection{Main prediction and discussion}

Combining (6) with (4) and (5), yields the prediction that an increase in "democracy" as measured by $H$, will stimulate innovation by advanced firms but not by backward ones. One should thus expect a higher impact of democracy on productivity growth in sectors that are closer to the world technological frontier.

We identify with democratic institutions the parameter $H$ in our model. This parameter captures the relative benefits of investing in a new technology relative to that of bribing a policy maker to make him raise barrier to entry. Bribes are certainly not unknown in democracies, but since they are more open, associated with more freedom of the press and involve alternation in power of different groups, democratic leaders are generally less likely to be permanently captured by incumbents. A different way of interpreting the evidence that we present below is to say that democracy enhance growth in technologically advanced sectors when democracy is associated with policies that allow more competition and more freedom of entry. In the empirical section which follows, we do indeed review evidence that imply a strong correlation between freedom of entry and democratic institutions as measured by indicators of political rights. 


\section{Empirical analysis}

\subsection{Data}

We use industry employment and value added data from the Industrial Statistics database collected by the UNIDO (2005, revision 2). ${ }^{7}$ The data include 28 ISIC (level 3) manufacturing sectors at the three digit level for 180 countries for the period 1963 to 2003 . UNIDO is arguably the most comprehensive source of sectorial data available in a cross-country-sector panel format ${ }^{8}$. The UNIDO data provide the most extensive coverage of developing countries sectorial output data available, a very important sub-sample for our study as most of them are partially free or not free from a political standpoint. However, a drawback of this source is the extensive use of national statistics, which tend to be especially noisy for industry-level data of developing countries.

For our empirical analysis two are the key independent variables: democracy and the distance to the technological frontier. In measuring the former we use standard, well-established measures of democracy in political economics, such as the aggregate indicators from the Polity IV database (2005) and the Freedom House measures of civil liberties and political rights. The Polity IV project records various regime characteristics for every independent state above half million total population. In particular we make use of the combined polity index ${ }^{9}$ ranging from -10 to $10(-10=$ high autocracy; $10=$ high democracy $)$. Such index incorporates more specific sub-indexes concerned with constraints on the executive, open political competition, effectiveness of legislature, etc. The Freedom in the World data by Freedom House report annual analysts' assessments of both political dimensions ${ }^{10}$ and civil dimensions ${ }^{11}$ since 1972 for more than 192

\footnotetext{
${ }^{7}$ Rajan and Zingales (1998) is one of the early seminal papers employing sectorial growth rates analysis.

${ }^{8}$ Other well-recognized sources of country-sector panel include OECD and ILO. However UNIDO employs OECD data forthe relevant subsample, while ILO produces employment data aggregated to the ISIC level-2, therefore more coarse than the data we employ here.

${ }^{9}$ We exclude special polity conditions such as transitions, interruptions, and interregnums as coded in the Polity IV database $-66 ;-77 ;-88$.

${ }^{10}$ Participate freely in the political process; Vote freely in legitimate elections; Have representatives that are accountable to them.

${ }^{11}$ Exercise freedoms of expression and belief; Be able to freely assemble and associate; Have access to an established and equitable system of rule of law; Have social and economic freedoms, including equal access to economic opportunities and the
} 
countries. For the Political Rights and Civil Liberties indexes, respectively; 1 represents the most free and 7 the least free rating. For consistency we re-scale both indexes in order to have 7 as the most free rating.

As for distance to the technological frontier we consider the logarithm of the value added per worker $(V A / E M P)$ of a sector divided by the maximum of the log of the same variable in the same sector across all countries in each year and take one minus this ratio as a proxy for distance to frontier. Specifically we define:

$$
\begin{aligned}
D I S T A N C E_{i c t} & =1-\frac{\left(V A_{i c t} / E M P_{i c t}\right)}{\max _{c^{\prime}}\left(V A_{i c^{\prime} t} / E M P_{i c^{\prime} t}\right)} \\
i & =\text { industry } ; c=\text { country } ; t=\text { year } .
\end{aligned}
$$

We also substituted log value added per worker with the logarithm of output per worker in order to construct an alternative measure of distance to frontier. We do not report results employing this variable, however, as they tend to be similar.

Finally, we make use of measures of entry barriers and costs of entry estimates as constructed by Djankov et al. (2002) and of real gross domestic product per capita in international dollars as reported in the Penn World Tables, mark 6.2. Summary statistics for the sample are reported, classified by year, in the Appendix Table A1.

\subsection{Specification}

On the left hand side of our regression we have the growth rate of either output $(Y)$, value added $(V A)$ or employment $(E M P)$ in the industrial sector. On the right hand side we have a measure of democracy (and other measures of political/civil rights), a measure of distance to the technological frontier, and the interaction term between the two. This term allows the marginal effect of democracy to vary with the proximity to the world's most productive technology. We also include time and country-industry fixed effects in order to account for contemporaneous shifts in world growth rates and unobserved heterogeneity across countries and industries. Thus, the empirical specification is as follows, where with $y_{i c t}$ we mean either output, value added or employment in industry $i$ of country $c$ at time $t$ :

right to hold private property. 


$$
\begin{aligned}
\Delta_{s} \log y_{i c t}= & \beta_{0}+\beta_{1} \text { DISTANCE } E_{i c t}+\beta_{2} P O L_{c t} \\
& +\beta_{3} D I S T A N C E_{i c t} * P O L_{c t}+\alpha X_{i c t}+u_{i c t} \\
\Delta_{s} \log y_{i c t}= & \log y_{i, c, t+s}-\log y_{i c t} \\
u_{i c t}= & \delta_{t}+\gamma_{i, c}+\varepsilon_{i, c, t+s} \\
s= & \{5,10\} \\
i= & \text { industry;c= country; } t=\text { year. }
\end{aligned}
$$

In the analysis we study 5-year and 10-years output, value added and employment sectorial growth rates. We compute growth rates over non-overlapping periods and in particular 5-years growth rates are computed over the periods 1970-75, 1975-80, 1980-85, 1985-90, 1990-95, and 1995-2000. For the 10-year growth rates we use alternatively the 1975-85, 1985-95 (odd) years and the 1980-90, and 1990-2000 (even years). Given the somewhat measurement-error prone nature of the data, we perceive this sample segmentation as a conservative approach. By employing this segmentation approach we are able to exclude issues of mechanical serial correlation present in a moving average setting. As we show below, indeed the results are sometimes influenced by the specific assumptions on sample periods. In a series of results that we do not report we also reestimate our main specification with yearly growth rates $(s=1)$. By and large the main implications of our discussion hold for this sampling choice as well. However, the degree of measurement error is substantial in UNIDO data at the yearly level, mostly because idiosyncrasies at the national statistical level are present, and results tend to be sometimes (and expectably) sensitive in this respect. By employing growth rates over longer periods of time signal to noise ratios tend to improve and ameliorate measurement error issues.

All the standard errors are robust and clustered at the country or country-industry level whenever possible, in order to account for general variance-covariance structures at the country-industry level within the panel setup. This approach is useful in order to address arbitrary forms of serial correlation in the error terms by allowing general variance-covariance structures within any industry-country error term.

The set of controls that we systematically include in any industry-country regression, $X_{i c t}$, include the level of real GDP per capita and its interaction with distance to frontier. The empirical model (7) is 
essentially a reduced-form specification and we do not intend to over-emphasize any channel of causation. A two-way causation mechanism is surely at work within a growth-democracy (or income-democracy) aggregate specification. The aim of this paper is to emphasize a significant differential role in the correlation between growth and democracy, this does not require the reader assigning causal interpretation to our finding.

\subsection{Basic Results}

Table 1 shows, in accordance to Acemoglu et al. (2005), that there is no effect of democracy on growth rates for manufacturing in a fixed-effects regression at the country level (obtained aggregating the UNIDO sectorial data at country-year level). If any, the effect of democracy on growth appears to be negative, since a few of the coefficients in the various regressions are significantly negative (even though most coefficients on democracy are insignificantly different from zero). Specifically, the upper panel (5-years growth rates) presents a split picture between value added and employment growth rates regressions. In the notation for this table (and the following ones) we employ the $L j$ operator notation for $j$-years lagged values. The middle panel (10-year growth for odd years) appears mostly positive and the lower panel (10-years even) presents mostly negative coefficients. These results are therefore consistent with what is found in the literature: no robust effects of democracy on aggregate growth.

Table 2 reports results on the effect of democracy on growth at the country-industry disaggregated level. The unit of observation becomes now a particular industry in a country at a specific moment in time. Still no effect of democracy is statistically or quantitatively significant in the data. Once again some of the coefficients of democracy (or political/civil rights) are negative and statistically different from zero. This table then shows that adding an extra dimension (industry level data) does not produce a departure from standard fixed effects country-level results per se. Notice that Table 2 introduces a control for the level of real gross domestic product per capita. We include a control for income levels (and its interactions when necessary) in order to partial out the effects of political institutions and of the level of economic development.

Table 3 introduces in specification at the country-industry level (7) an interaction term between democracy and distance from the technological frontier. We report results concerning output, value added and employment for all sample periods (5-year; the even and odd 10-year). This interaction matters statistically 
and quantitatively in most specifications and enters with a negative and significant coefficient. The table shows that introducing a differential effect of distance to the technological frontier and democracy explains the data better in terms of fit. The sign of the interaction between distance to frontier and democracy is usually negative, while the level of democracy is positive. The result indicates that when close to the technological frontier, the effect of democracy on growth is positive. However, far away from the technological frontier the effect of democracy may be growth-diminishing. This can be interpreted as the basic reduced-form implication of the theoretical model we built. Finally, we interpret the positive sign of the coefficient associated with the regressor DISTANCE as evidence of convergence, a robust and recurrent finding in the empirical economic growth literature. Notice also that a component of convergence is also captured (predictably) by the level of GDP per capita which present a negative sign (growth rates are lower in countries with higher levels of GDP per capita). The interaction term between GDP per capita and distance to frontier is usually negative, although mostly insignificant.

Concerning quantitative implications of Table 3, let us begin from the first panel (5-year growth rates), recalling that the Polity index ranges from -10 to +10 , increasing in the level of democratic freedom. The statistically and quantitatively significant results concern the value added and the employment growth regressions (columns 4-9) and the political rights and civil liberty indexes. In general output growth regressions tend to appear more noisy and so do regressions employing the Polity IV index as a proxy for democracy in the right-end side.

Column (5) implies that the effect of an increase of a unit point on the Polity IV scale of democracy for a sector that operates with the most advanced technology (i.e. distance from the frontier is 0 ) has the effect of increasing the growth rate of value added of 1.2 percent. However at the mean distance to frontier in the sample (0.16) the effect of a similar increase in democracy on the growth rate of value added decreases to -1 percent. Notice that this figure is roughly consistent with the results of Table 2. Considering a technology half the productivity of the world frontier we would find a really substantial effect of an increase of a Polity IV unit of democracy: a drop of -5.7 percent. The unit measure for political rights and civil liberties is different from the Polity IV index, ranging from 1 to 7 (rescaled so that 7 indicates full democracy and 1 full autocracy). Once the coefficients are scaled for the unit of measurement, the results employing Freedom 
House data (columns 2 and 3) confirm the column (1)'s estimates.

Results systematically present more beneficial effects of democracy when we use as left-hand-side variable the sector's employment growth. In column (8) the effect of an increase of a unit point on the Polity IV scale of democracy for a sector that operates with the most advanced technology (i.e. distance from the frontier is 0) has the effect of increasing the growth rate of value added of 3.9 percent. At the mean distance to frontier the effect of a similar increase in democracy on the growth rate of employment is -0.7 percent.

Considering the 10-year growth rates for both the even years and the odd years samples we maintain the finding of a negative interaction term and a positive coefficient on the level of democracy in the majority of the specifications, albeit with some exceptions that we tend to attribute to the demanding nature of our three-way fixed-effects specification. The result confirm a positive role of democracy especially when close to the technological frontier. Consider column (1) of the odd-years panel. The estimated effects are consistent with the 5 -years growth rates but not statistically significant. Again the results on employment growth rates are stronger.

Overall these results, including many other specification tests which we performed and are available upon request $^{12}$, suggest that our intuition of a differential effects of democracy in different sectors as a function of distance form the frontier is plausible. However, as the last part of Table 3 shows, some degree of sensitivity of the results to certain specification or measurement issues remains evident.

\subsection{Entry and Democracy}

The previous section presents evidence of differential effects of political institutions on sectorial performance, depending on the specific characteristics of each industry. In this section we make some progress in the investigation of a channel, especially focusing on entry barriers.

In the model of Section 2 we discussed the role of freedom of entry and we assumed a correlation between freedom of entry and political freedom. In Appendix Table A2 we report evidence that democracies do

\footnotetext{
${ }^{12}$ Among the additional tests we performed are: change of sampling frequency (yearly panel results; modified dates for the computation of the sample changes); specification changes (including quadratic terms of the democracy index); exclusion of country or sector fixed effects.
} 
indeed have lower barriers and cost of entry by employing the Djankov et al. (2002) cross-country data on regulation of entry. Indeed, a table similar to A2 is also present in the original Djankov et al. (2002) paper and here it is reported only for completeness of the argument. The left-hand-side variable is a measure of the cost of entry given by the number of bureaucratic procedures needed for a firm to enter the market (number of procedures necessary to start up a business), available from the Doing Business project by the World Bank. All measures of democratic development (constraints on the executives, political and civil rights, et similar) present a negative correlation with entry costs, even controlling for income levels. Notice that in addition to the Polity IV autocracy index and Freedom House political and civil rights indexes we also report results employing all the additional measures of democracy and political liberties that Djankov et al. (2002) employ, such as the Polity IV sub-indexes of executive de facto independence; constraints on executive power; effectiveness of legislature; government effectiveness; competition in the legislative nominating process.

Perotti and Volpin (2006) study in detail the cross national determinants of investor protection and entry. They present convincing evidence that "countries with more accountable political institutions have better investor protection and lower entry costs". Note that, as they point out, poor investor protection is indirectly a barrier for entry since new investors face higher risks in entering a new market. Perotti and Volpin (2006) also use POLITY IV as a measure of political accountability but the experiment with several others finding consistently a strong correlation between democracy and freedom of entry.

A direct way of relating our approach to past literature would be to consider the differential effect of democracy and entry using as a proxy for the probability of entry of a competitor the number of procedures needed to start up a business in the country as reported by Djankov et. al. (2002). We could check if, controlling for a differential effect of entry, the role of democracy and the significance of the interaction term change. Given the cross-sectional nature of the cost of entry variables only the interaction term between entry cost and distance can be added to the specification of Table 3.

Although promising in principle, this approach did not yield any statistically relevant result in our attempts. In tables available from the authors we considered this approach, with and without controls for GDP levels. The estimates of the coefficients on democracy and its interaction with distance seemed to be unaffected by introducing this particular measure of entry costs interacted with distance. Considering the 
5-year growth rate sample and the 10-year rates for both even and odd dates presents a noisy picture at best: the marginal effects of democracy at different distances become somewhat smaller but the proxy for entry is always insignificant and often with the wrong sign. This is also true if we add further interactions on property rights protection, which we explored as well. The results on democracy and the interaction with distance remain generally significant and with a positive and a negative sign respectively. These results taken together suggest either that the Polity IV and Freedom House variables capture something more general than the number of procedures regarding the possibility of entry and competition or that a purely cross-sectional measure of cost of entry as the one proposed by Djankov et. al. (2002) does not present sufficient variation to allow our three-way panel setup (industry-country-time, which is indeed fairly demanding in this respect) to pick up any significant relationship with growth.

In order to provide a reasonable amount of variation in the data in Table 4 we replace the number of procedures with the effective level of entry in the sector, measured by the 5-year or 10-year growth rates in the number of establishments. Notice that the growth rate in the number of establishment is a realized (ex post) measure of entry and one could argue about whether or not is the relevant covariate to influence the pattern of innovation discussed in the model, as opposed to ex ante proxies. Clearly a point in favor of our approach is the scarcity of alternatives in terms of time-varying proxies of entry.

The time-varying entry variable allows to control for both the level of entry and its interaction with distance to frontier. However, the UNIDO data do not include information on the number of establishments before the eighties, therefore limiting the sample period for the analysis. In addition, casual inspection of the original data indicates a somewhat more noisy nature of the establishment figures relative to employment and value added figures, with somewhat large (abnormal) jumps (which we decide not to censor in the analysis).

The effect of democracy is now reduced substantially. If we interpret effective entry as a precise proxy for entry costs, this finding tends to support our interpretation of the data. However, only for the 10year sample the marginal effects of entry depend on the distance to frontier in a direction in line with the model's prediction. Entry in levels has a positive and significant effect in all regressions and the interaction with distance is instead negative. Statistically significant coefficients on the interaction between entry and distance are present for both sectorial output and value added. The effect of democracy is generally negative 
at the mean distance to frontier (0.16), but the coefficients on democracy and its interaction with distance are significant only in the case of political rights. This suggests that indeed an entry channel may explain why democracy is conducive to growth in sectors closer to the technological frontier rather than other less advanced sectors, at least over relatively long periods of time (10 years).

\section{Conclusions}

This paper investigates a different approach and some novel empirical evidence on the relationship between democracy, level of development, and economic growth by employing disaggregated data on industrial sectors' growth rates. We have argued (and shown empirically with some degree of success) that democratic institutions favor growth in sectors of the economy that are particularly advanced in terms of value added per worker, or in our terminology, close to the world technological frontier. Our interpretation is that it is in sectors close to the technological frontier that democracy is more beneficial, possibly through fostering entry, competition, and innovation, which are relatively more important for growth in those sectors. Thus our analysis introduces a technological motive for political freedom survival, a dimension that has not received much attention in the wide empirical literature on democratization. It also suggests that the demand for democracy should be higher in richer countries, that is in which more sectors are closer to the technological frontier.

In a general sense this paper contributes to the strand of the politico-economic literature focusing on the differential effects of political institutions on economic outcomes. The same institutional features may have quite different effects on different components of the economy.

Natural next steps in this research program would be, first, to dig further into the various channels whereby democracy fosters growth in more advanced sectors, and, second, to analyze the process by which the economic demand for democracy may or may not translate into a real transition to democracy. 


\section{References}

Acemoglu, Daron (2007), "Oligarchic Versus Democratic Societies", forthcoming, Journal of the European Economic Association

Acemoglu, Daron, Aghion, Philippe, and Zilibotti, Fabrizio (2006), "Distance to Frontier, Selection and Economic Growth", Journal of the European Economic Association, 4(1), 37-74.

Acemoglu, Daron, Johnson, Simon, Robinson, James, and Yared, Pierre (2005), "Income and Democracy", Mimeo, MIT.

Aghion, Philippe, Alesina, Alberto, and Trebbi Francesco (2004) " Endogenous Political Institutions", Quarterly Journal of Economics, 119(2), 565-611.

Aghion, Philippe, Burgess, Robin, Redding, Stephen and Zilibotti, Fabrizio (2006), "The Unequal Effects of Liberalization: Evidence from Dismantling the License Raj in India", NBER working papers No 12031.

Barro, Robert (1996), "Democracy and Growth", Journal of Economic Growth 1, 1-27.

Barro, Robert (1999), "The Determinants of Democracy", Journal of Political Economy 107, S158-S183.

Barro, Robert and Lee, Jong-Wha (2000), "International Data on Educational Attainment: Updates and Implications," CID Working Paper, No 42.

Boix, Carlos (2003), Democracy and Redistribution, Cambridge University Press.

Bueno de Mesquita, Bruce, Smith, Alastair, Siverson, Randolph and Morrow, James (2003), The Logic of Political Survival, The MIT Press.

Djankov, Simon, LaPorta, Raphael, Lopez-de-Silanes, Florencio and Shleifer, Andrei (2002), "The Regulation of Entry", Quarterly Journal of Economics, 113, 1-37.

Gerring, John, Bond, Philip, Barndt, William T. and Moreno, Carola (2005), "Democracy and Economic Growth: A Historical Perspective", World Politics 57, 323-364. 
Giavazzi, Francesco and Tabellini, Guido (2005), "Economic and Political Liberalizations", Journal of Monetary Economics, 52, 1297-1330.

Gibson, James (1997), "Mass Opposition to the Soviet Putsch of August 1991: Collective Action, Rational Choice, and Democratic Values in the Former Soviet Union", American Political Science Review 91, 671-84.

Glaeser, Edward., La Porta, Rafael, Lopez de Silanes, Florencio, and Shleifer, Andrei (2004) "Do Institutions Cause Growth", Journal of Economic Growth 9, 271-304.

Helliwell, John. (1994). "Empirical Linkages Between Democracy and Economic Growth", British Journal of Political Science 24, 225-248.

Huntington, Samuel (1991), The Third Wave: Democratization in the Late Twentieth Century, University of Oklahoma Press.

Inglehart, Ronald, and Welzel, Christian (2005), Modernization, Cultural Change, and Democracy: The Human Development Sequence, Cambridge University Press.

Jenkins, Stephen (2004), Survival Analysis, Mimeo, University of Essex.

Jones, Ben and Olken, Benjamin (2005), "Do Leaders Matter? National Leadership and Growth since World War II", Quarterly Journal of Economics 120, 835-864.

LaPorta, Raphael, Lopez-De-Silanes, Florencio, Shleifer, Andrei, and Vishny, Robert (1999). "The Quality of Government", The Journal of Law, Economics and Organization 15, 222-79.

Lipset, Seymour Martin (1959), "Some Social Requisites of Democracy: Economic Development and Political Legitimacy", American Political Science Review 53, 69-105.

Londregan, John, and Poole, Keith (1990), "Poverty, the Coup Trap, and the Seizure of Executive Power", World Politics 42, 151-183.

Maddison, Angus (2001), The World Economy: Historical Statistics, OECD. 
Morris, Stephen and Shin, Hyun (2002), "Global Games: Theory and Applications", in Dewatripont, Mathias, Hansen, Lars and Turnovsky, Stephen (eds.), Advances in Economics and Econometrics, The Eighth World Congress, Cambridge University Press.

Mulligan, Casey B., Sala-i-Martin, Xavier and Gil, Ricard (2004), "Do Democracies Have Different Public Policies than Nondemocracies?", Journal of Economic Perspectives 18, 51-74.

Opp, Karl-Dieter (1999), "Contending Conceptions of the Theory of Rational Action", Journal of Theoretical Politics 11, 171-202.

Papaioannou, Elias, and Siourounis, Gregorios (2004), "Democratization and Growth", Mimeo, LBS.

Perotti, Enrico and Volpin, Eduardo (2006) "Investor Protection and Entry" unpublished

Persson, Torsten and Tabellini, Guido (2006) "Democratic Capital: The Nexus of Political and Economic Change" NBER Working Papers No 12175.

Przeworski, Adam, Alvarez, Michael, Cheibub, Jose, and Limongi, Fernando (2000), Democracy and Development: Political Institutions and Well-Being in the World 1950-1900, Cambridge University Press.

Przeworski, Adam and Limongi, Fernando (1993), "Political Regimes and Economic Growth", Journal of Economic Perspectives 7, 51-69.

Rajan, Raghuram, and Zingales, Luigi (1998) "Financial Dependence and Growth", American Economic Review 88, 559-586.

Rodrik, Dani and Wacziarg, Romain (2005), "Do Democratic Transitions Produce Bad Economic Outcomes?", American Economic Review Papers and Proceedings 95, 50-56. 
Table 1: Aggregate manufacturing growth and democracy

\begin{tabular}{|c|c|c|c|c|c|c|c|c|c|}
\hline & $\begin{array}{l}\text { F.E. } \\
\text { country } \\
\text { year }\end{array}$ & $\begin{array}{l}\text { F.E. } \\
\text { country } \\
\text { year }\end{array}$ & $\begin{array}{l}\text { F.E. } \\
\text { country } \\
\text { year }\end{array}$ & $\begin{array}{l}\text { F.E. } \\
\text { country } \\
\text { year }\end{array}$ & $\begin{array}{l}\text { F.E. } \\
\text { country } \\
\text { year }\end{array}$ & $\begin{array}{l}\text { F.E. } \\
\text { country } \\
\text { year }\end{array}$ & $\begin{array}{l}\text { F.E. } \\
\text { country } \\
\text { year }\end{array}$ & $\begin{array}{l}\text { F.E. } \\
\text { country } \\
\text { year }\end{array}$ & $\begin{array}{l}\text { F.E. } \\
\text { country } \\
\text { year }\end{array}$ \\
\hline $1975-80-85-90-95-00$ & $\begin{array}{l}5 \text {-year } \\
\text { Output } \\
\text { growth rate }\end{array}$ & $\begin{array}{l}5 \text {-year } \\
\text { Output } \\
\text { growth rate }\end{array}$ & $\begin{array}{l}5 \text {-year } \\
\text { Output } \\
\text { growth rate }\end{array}$ & $\begin{array}{l}5 \text {-year } \\
\text { Value } \\
\text { added } \\
\text { growth rate }\end{array}$ & $\begin{array}{l}5 \text {-year } \\
\text { Value } \\
\text { added } \\
\text { growth rate }\end{array}$ & $\begin{array}{l}5 \text {-year } \\
\text { Value } \\
\text { added } \\
\text { growth rate }\end{array}$ & $\begin{array}{l}5 \text {-year } \\
\text { Employme } \\
\text { nt growth } \\
\text { rate }\end{array}$ & $\begin{array}{l}5 \text {-year } \\
\text { Employme } \\
\text { nt growth } \\
\text { rate }\end{array}$ & $\begin{array}{l}\text { 5-year } \\
\text { Employme } \\
\text { nt growth } \\
\text { rate }\end{array}$ \\
\hline L5. Dem. polityIV & $\begin{array}{l}0.001 \\
{[0.006]}\end{array}$ & & & $\begin{array}{l}-0.003 \\
{[0.005]}\end{array}$ & & & $\begin{array}{l}-0.009 \\
{[0.005]^{*}}\end{array}$ & & \\
\hline L5. Polit. rights & & $\begin{array}{l}0.023 \\
{[0.024]}\end{array}$ & & & $\begin{array}{l}-0.014 \\
{[0.023]}\end{array}$ & & & $\begin{array}{l}0.003 \\
{[0.016]}\end{array}$ & \\
\hline L5. Civil liberty & & & $\begin{array}{l}0.029 \\
{[0.031]}\end{array}$ & & & $\begin{array}{l}-0.036 \\
{[0.033]}\end{array}$ & & & $\begin{array}{l}-0.008 \\
{[0.022]}\end{array}$ \\
\hline Observations & 627 & 591 & 591 & 405 & 362 & 362 & 438 & 411 & 411 \\
\hline Number of countries & 133 & 148 & 148 & 106 & 111 & 111 & 116 & 130 & 130 \\
\hline$\underline{\mathrm{R} \text {-squared }}$ & 0.08 & 0.08 & 0.08 & 0.34 & 0.26 & 0.27 & 0.12 & 0.06 & 0.06 \\
\hline 1975-1985-1995 & $\begin{array}{l}10 \text {-year } \\
\text { Output } \\
\text { growth rate }\end{array}$ & $\begin{array}{l}10 \text {-year } \\
\text { Output } \\
\text { growth rate }\end{array}$ & $\begin{array}{l}10 \text {-year } \\
\text { Output } \\
\text { growth rate }\end{array}$ & $\begin{array}{l}10 \text {-year } \\
\text { Value } \\
\text { added } \\
\text { growth rate }\end{array}$ & $\begin{array}{l}10 \text {-year } \\
\text { Value } \\
\text { added } \\
\text { growth rate }\end{array}$ & $\begin{array}{l}10 \text {-year } \\
\text { Value } \\
\text { added } \\
\text { growth rate }\end{array}$ & $\begin{array}{l}10 \text {-year } \\
\text { Employme } \\
\text { nt growth } \\
\text { rate }\end{array}$ & $\begin{array}{l}\text { 10-year } \\
\text { Employme } \\
\text { nt growth } \\
\text { rate }\end{array}$ & $\begin{array}{l}10 \text {-year } \\
\text { Employme } \\
\text { nt growth } \\
\text { rate }\end{array}$ \\
\hline L10. Dem. polityIV & $\begin{array}{l}-0.003 \\
{[0.007]}\end{array}$ & & & $\begin{array}{l}0.007 \\
{[0.013]}\end{array}$ & & & $\begin{array}{l}0.001 \\
{[0.012]}\end{array}$ & & \\
\hline L10. Polit. rights & & $\begin{array}{l}0.05 \\
{[0.038]}\end{array}$ & & & $\begin{array}{l}0.002 \\
{[0.081]}\end{array}$ & & & $\begin{array}{l}0.102 \\
{[0.055]^{*}}\end{array}$ & \\
\hline L10. Civil liberty & & & $\begin{array}{l}0.05 \\
{[0.051]}\end{array}$ & & & $\begin{array}{l}0.057 \\
{[0.065]}\end{array}$ & & & $\begin{array}{l}-0.046 \\
{[0.077]}\end{array}$ \\
\hline Observations & 277 & 226 & 226 & 181 & 142 & 142 & 190 & 157 & 157 \\
\hline $\begin{array}{l}\text { Number of countries } \\
\text { R-squared }\end{array}$ & $\begin{array}{l}111 \\
0.13\end{array}$ & $\begin{array}{l}121 \\
0.14\end{array}$ & $\begin{array}{l}121 \\
0.14\end{array}$ & $\begin{array}{l}82 \\
0.37\end{array}$ & $\begin{array}{l}82 \\
0.29\end{array}$ & $\begin{array}{l}82 \\
0.3\end{array}$ & $\begin{array}{l}87 \\
0.09\end{array}$ & $\begin{array}{l}92 \\
0.03\end{array}$ & $\begin{array}{l}92 \\
0.02\end{array}$ \\
\hline 1980-1990-2000 & $\begin{array}{l}10 \text {-year } \\
\text { Output } \\
\text { growth rate }\end{array}$ & $\begin{array}{l}10 \text {-year } \\
\text { Output } \\
\text { growth rate }\end{array}$ & $\begin{array}{l}10 \text {-year } \\
\text { Output } \\
\text { growth rate }\end{array}$ & $\begin{array}{l}\text { 10-year } \\
\text { Value } \\
\text { added } \\
\text { growth rate }\end{array}$ & $\begin{array}{l}\text { 10-year } \\
\text { Value } \\
\text { added } \\
\text { growth rate }\end{array}$ & $\begin{array}{l}\text { 10-year } \\
\text { Value } \\
\text { added } \\
\text { growth rate }\end{array}$ & $\begin{array}{l}\text { 10-year } \\
\text { Employme } \\
\text { nt growth } \\
\text { rate }\end{array}$ & $\begin{array}{l}10 \text {-year } \\
\text { Employme } \\
\text { nt growth } \\
\text { rate }\end{array}$ & $\begin{array}{l}\text { 10-year } \\
\text { Employme } \\
\text { nt growth } \\
\text { rate }\end{array}$ \\
\hline L10. Dem. polityIV & $\begin{array}{l}0.02 \\
{[0.010]^{*}}\end{array}$ & & & $\begin{array}{l}-0.009 \\
{[0.008]}\end{array}$ & & & $\begin{array}{l}-0.022 \\
{[0.008]^{* * *}}\end{array}$ & & \\
\hline L10. Polit. rights & & $\begin{array}{l}0.087 \\
{[0.051]^{*}}\end{array}$ & & & $\begin{array}{l}-0.028 \\
{[0.053]}\end{array}$ & & & $\begin{array}{l}-0.07 \\
{[0.046]}\end{array}$ & \\
\hline L10. Civil liberty & & & $\begin{array}{l}0.098 \\
{[0.089]}\end{array}$ & & & $\begin{array}{l}-0.04 \\
{[0.053]}\end{array}$ & & & $\begin{array}{l}-0.084 \\
{[0.042]^{* *}}\end{array}$ \\
\hline Observations & 290 & 217 & 217 & 184 & 121 & 121 & 194 & 133 & 133 \\
\hline Number of countries & 111 & 119 & 119 & 82 & 77 & 77 & 89 & 85 & 85 \\
\hline R-squared & 0.04 & 0.05 & 0.04 & 0.45 & 0.01 & 0.01 & 0.27 & 0.15 & 0.15 \\
\hline
\end{tabular}


Table 2: Growth by sector and democracy

\begin{tabular}{|c|c|c|c|c|c|c|c|c|c|}
\hline & $\begin{array}{l}\text { F.E. SIC } \\
\text { country } \\
\text { year }\end{array}$ & $\begin{array}{l}\text { F.E. SIC } \\
\text { country } \\
\text { year }\end{array}$ & $\begin{array}{l}\text { F.E. SIC } \\
\text { country } \\
\text { year }\end{array}$ & $\begin{array}{l}\text { F.E. SIC } \\
\text { country } \\
\text { year }\end{array}$ & $\begin{array}{l}\text { F.E. SIC } \\
\text { country } \\
\text { year }\end{array}$ & $\begin{array}{l}\text { F.E. SIC } \\
\text { country } \\
\text { year }\end{array}$ & $\begin{array}{l}\text { F.E. SIC } \\
\text { country } \\
\text { year }\end{array}$ & $\begin{array}{l}\text { F.E. SIC } \\
\text { country } \\
\text { year }\end{array}$ & $\begin{array}{l}\text { F.E. SIC } \\
\text { country } \\
\text { year }\end{array}$ \\
\hline 1975-80-85-90-95-00 & $\begin{array}{l}5 \text {-year } \\
\text { Output } \\
\text { growth } \\
\text { rate }\end{array}$ & $\begin{array}{l}5 \text {-year } \\
\text { Output } \\
\text { growth } \\
\text { rate }\end{array}$ & $\begin{array}{l}5 \text {-year } \\
\text { Output } \\
\text { growth } \\
\text { rate }\end{array}$ & $\begin{array}{l}5 \text {-year } \\
\text { Value } \\
\text { added } \\
\text { growth } \\
\text { rate }\end{array}$ & $\begin{array}{l}5 \text {-year } \\
\text { Value } \\
\text { added } \\
\text { growth } \\
\text { rate }\end{array}$ & $\begin{array}{l}5 \text {-year } \\
\text { Value } \\
\text { added } \\
\text { growth } \\
\text { rate }\end{array}$ & $\begin{array}{l}5 \text {-year } \\
\text { Employme } \\
\text { nt growth } \\
\text { rate }\end{array}$ & $\begin{array}{l}5 \text {-year } \\
\text { Employme } \\
\text { nt growth } \\
\text { rate }\end{array}$ & $\begin{array}{l}5 \text {-year } \\
\text { Employme } \\
\text { nt growth } \\
\text { rate }\end{array}$ \\
\hline L5. Dem. polityIV & $\begin{array}{l}0.002 \\
{[0.002]}\end{array}$ & & & $\begin{array}{l}0.001 \\
{[0.002]}\end{array}$ & & & $\begin{array}{l}-0.008 \\
{[0.001]^{* * *}}\end{array}$ & & \\
\hline L5. Polit. rights & & $\begin{array}{l}-0.004 \\
{[0.009]}\end{array}$ & & & $\begin{array}{l}-0.006 \\
{[0.009]}\end{array}$ & & & $\begin{array}{l}-0.012 \\
{[0.006]^{*}}\end{array}$ & \\
\hline L5. Civil liberty & & & $\begin{array}{l}-0.015 \\
{[0.010]}\end{array}$ & & & $\begin{array}{l}-0.015 \\
{[0.011]}\end{array}$ & & & $\begin{array}{l}-0.012 \\
{[0.007]^{*}}\end{array}$ \\
\hline L5. Real GDP per capita & $\begin{array}{l}-0.321 \\
{[0.048]^{* * *}}\end{array}$ & $\begin{array}{l}-0.518 \\
{[0.057]^{* * *}}\end{array}$ & $\begin{array}{l}-0.505 \\
{[0.058]^{* * *}}\end{array}$ & $\begin{array}{l}-0.155 \\
{[0.049]^{* * *}}\end{array}$ & $\begin{array}{l}-0.397 \\
{[0.059]^{* * *}}\end{array}$ & $\begin{array}{l}-0.384 \\
{[0.060]^{* * *}}\end{array}$ & $\begin{array}{l}-0.141 \\
{[0.031]^{* * *}}\end{array}$ & $\begin{array}{l}-0.178 \\
{[0.038]^{* * *}}\end{array}$ & $\begin{array}{l}-0.17 \\
{[0.038]^{* * *}}\end{array}$ \\
\hline Observations & 9250 & 8234 & 8234 & 9412 & 8078 & 8078 & 10097 & 8932 & 8932 \\
\hline Number of countries & 2579 & 2650 & 2650 & 2408 & 2447 & 2447 & 2619 & 2779 & 2779 \\
\hline R-squared & 0.3 & 0.26 & 0.26 & 0.26 & 0.22 & 0.22 & 0.08 & 0.05 & 0.05 \\
\hline $\begin{array}{l}\text { 1975-1985-1995 } \\
\text { L10. Dem. polityIV }\end{array}$ & $\begin{array}{l}\begin{array}{l}10 \text {-year } \\
\text { Output } \\
\text { growth } \\
\text { rate }\end{array} \\
0.003 \\
{[0.006]}\end{array}$ & $\begin{array}{l}10 \text {-year } \\
\text { Output } \\
\text { growth } \\
\text { rate }\end{array}$ & $\begin{array}{l}10 \text {-year } \\
\text { Output } \\
\text { growth } \\
\text { rate }\end{array}$ & $\begin{array}{l}10 \text {-year } \\
\text { Value } \\
\text { added } \\
\text { growth } \\
\text { rate } \\
-0.002 \\
{[0.006]}\end{array}$ & $\begin{array}{l}10 \text {-year } \\
\text { Value } \\
\text { added } \\
\text { growth } \\
\text { rate }\end{array}$ & $\begin{array}{l}10 \text {-year } \\
\text { Value } \\
\text { added } \\
\text { growth } \\
\text { rate }\end{array}$ & $\begin{array}{l}10 \text {-year } \\
\text { Employme } \\
\text { nt growth } \\
\text { rate } \\
0.007 \\
{[0.004]^{*}}\end{array}$ & $\begin{array}{l}\text { 10-year } \\
\text { Employme } \\
\text { nt growth } \\
\text { rate }\end{array}$ & $\begin{array}{l}10 \text {-year } \\
\text { Employme } \\
\text { nt growth } \\
\text { rate }\end{array}$ \\
\hline L10. Polit. rights & & $\begin{array}{l}-0.001 \\
{[0.031]}\end{array}$ & & & $\begin{array}{l}-0.043 \\
{[0.031]}\end{array}$ & & & $\begin{array}{l}0.017 \\
{[0.019]}\end{array}$ & \\
\hline L10. Civil liberty & & & $\begin{array}{l}0.104 \\
{[0.031]^{* * *}}\end{array}$ & & & $\begin{array}{l}0.135 \\
{[0.030]^{* * *}}\end{array}$ & & & $\begin{array}{l}0.008 \\
{[0.022]}\end{array}$ \\
\hline L10. Real GDP per capita & $\begin{array}{l}-0.239 \\
{[0.119]^{* *}}\end{array}$ & $\begin{array}{l}-0.142 \\
{[0.182]}\end{array}$ & $\begin{array}{l}-0.163 \\
{[0.184]}\end{array}$ & $\begin{array}{l}-0.04 \\
{[0.113]}\end{array}$ & $\begin{array}{l}0.064 \\
{[0.171]}\end{array}$ & $\begin{array}{l}0.04 \\
{[0.173]}\end{array}$ & $\begin{array}{l}-0.428 \\
{[0.085]^{* * *}}\end{array}$ & $\begin{array}{l}-0.356 \\
{[0.129]^{* * *}}\end{array}$ & $\begin{array}{l}-0.35 \\
{[0.129]^{* * *}}\end{array}$ \\
\hline Observations & 4103 & 3217 & 3217 & 4164 & 3183 & 3183 & 4386 & 3486 & 3486 \\
\hline Number of countries & 1963 & 1950 & 1950 & 1941 & 1867 & 1867 & 2038 & 2032 & 2032 \\
\hline R-squared & 0.19 & 0.07 & 0.07 & 0.17 & 0.07 & 0.08 & 0.1 & 0.01 & 0.01 \\
\hline 1980-1990-2000 & $\begin{array}{l}10 \text {-year } \\
\text { Output } \\
\text { growth } \\
\text { rate }\end{array}$ & $\begin{array}{l}10 \text {-year } \\
\text { Output } \\
\text { growth } \\
\text { rate }\end{array}$ & $\begin{array}{l}10 \text {-year } \\
\text { Output } \\
\text { growth } \\
\text { rate }\end{array}$ & $\begin{array}{l}10 \text {-year } \\
\text { Value } \\
\text { added } \\
\text { growth } \\
\text { rate }\end{array}$ & $\begin{array}{l}10 \text {-year } \\
\text { Value } \\
\text { added } \\
\text { growth } \\
\text { rate }\end{array}$ & $\begin{array}{l}10 \text {-year } \\
\text { Value } \\
\text { added } \\
\text { growth } \\
\text { rate }\end{array}$ & $\begin{array}{l}10 \text {-year } \\
\text { Employme } \\
\text { nt growth } \\
\text { rate }\end{array}$ & $\begin{array}{l}\text { 10-year } \\
\text { Employme } \\
\text { nt growth } \\
\text { rate }\end{array}$ & $\begin{array}{l}10 \text {-year } \\
\text { Employme } \\
\text { nt growth } \\
\text { rate }\end{array}$ \\
\hline L10. Dem. polityIV & $\begin{array}{l}-0.001 \\
{[0.003]}\end{array}$ & & & $\begin{array}{l}-0.006 \\
{[0.003]^{*}}\end{array}$ & & & $\begin{array}{l}-0.013 \\
{[0.003]^{* * *}}\end{array}$ & & \\
\hline L10. Polit. rights & & $\begin{array}{l}-0.006 \\
{[0.020]}\end{array}$ & & & $\begin{array}{l}-0.012 \\
{[0.021]}\end{array}$ & & & $\begin{array}{l}-0.044 \\
{[0.016]^{* * *}}\end{array}$ & \\
\hline L10. Civil liberty & & & $\begin{array}{l}0.01 \\
{[0.024]}\end{array}$ & & & $\begin{array}{l}-0.028 \\
{[0.026]}\end{array}$ & & & $\begin{array}{l}-0.049 \\
{[0.018]^{* * *}}\end{array}$ \\
\hline L10. Real GDP per capita & $\begin{array}{l}-0.715 \\
{[0.096]^{* * *}}\end{array}$ & $\begin{array}{l}-1.044 \\
{[0.159]^{* * *}}\end{array}$ & $\begin{array}{l}-1.059 \\
{[0.160]^{* * *}}\end{array}$ & $\begin{array}{l}-0.592 \\
{[0.101]^{* * *}}\end{array}$ & $\begin{array}{l}-0.984 \\
{[0.166]^{* * *}}\end{array}$ & $\begin{array}{l}-0.958 \\
{[0.166]^{* * *}}\end{array}$ & $\begin{array}{l}-0.379 \\
{[0.072]^{* * *}}\end{array}$ & $\begin{array}{l}-0.203 \\
{[0.103]^{* *}}\end{array}$ & $\begin{array}{l}-0.165 \\
{[0.106]}\end{array}$ \\
\hline Observations & 4060 & 2661 & 2661 & 4294 & 2682 & 2682 & 4485 & 2874 & 2874 \\
\hline Number of countries & 1873 & 1685 & 1685 & 1962 & 1693 & 1693 & 2087 & 1811 & 1811 \\
\hline R-squared & 0.45 & 0.1 & 0.1 & 0.37 & 0.09 & 0.09 & 0.17 & 0.03 & 0.03 \\
\hline
\end{tabular}


Table 3: Differential effect of democracy depending on distance to frontier

\begin{tabular}{|c|c|c|c|c|c|c|c|c|c|}
\hline & $\begin{array}{l}\text { F.E. SIC } \\
\text { country } \\
\text { year }\end{array}$ & $\begin{array}{l}\text { F.E. SIC } \\
\text { country } \\
\text { year }\end{array}$ & $\begin{array}{l}\text { F.E. SIC } \\
\text { country } \\
\text { year }\end{array}$ & $\begin{array}{l}\text { F.E. SIC } \\
\text { country } \\
\text { year }\end{array}$ & $\begin{array}{l}\text { F.E. SIC } \\
\text { country } \\
\text { year }\end{array}$ & $\begin{array}{l}\text { F.E. SIC } \\
\text { country } \\
\text { year }\end{array}$ & $\begin{array}{l}\text { F.E. SIC } \\
\text { country } \\
\text { year }\end{array}$ & $\begin{array}{l}\text { F.E. SIC } \\
\text { country } \\
\text { year }\end{array}$ & $\begin{array}{l}\text { F.E. SIC } \\
\text { country } \\
\text { year }\end{array}$ \\
\hline & 5 -year & 5 -year & 5 -year & & & & 5-year & 5-year & 5-year \\
\hline 1975-80-85-90-95-00 & $\begin{array}{l}\text { Output } \\
\text { growth } \\
\text { rate }\end{array}$ & $\begin{array}{l}\text { Output } \\
\text { growth } \\
\text { rate }\end{array}$ & $\begin{array}{l}\text { Output } \\
\text { growth } \\
\text { rate }\end{array}$ & $\begin{array}{l}5 \text {-year VA } \\
\text { growth } \\
\text { rate }\end{array}$ & $\begin{array}{l}\text { 5-year VA } \\
\text { growth } \\
\text { rate }\end{array}$ & $\begin{array}{l}5 \text {-year VA } \\
\text { growth } \\
\text { rate }\end{array}$ & $\begin{array}{l}\text { Emp. } \\
\text { growth } \\
\text { rate }\end{array}$ & $\begin{array}{l}\text { Emp. } \\
\text { growth } \\
\text { rate }\end{array}$ & $\begin{array}{l}\text { Emp. } \\
\text { growth } \\
\text { rate }\end{array}$ \\
\hline \multirow[t]{2}{*}{ L5. Distance to frontier in VA/Emp } & 4.283 & 5.939 & 6.044 & 5.06 & 6.307 & 6.262 & 0.873 & 1.845 & 1.626 \\
\hline & {$[1.259]^{* * *}$} & {$[1.588]^{* * *}$} & {$[1.588]^{* * *}$} & {$[1.308]^{* * *}$} & {$[1.707]^{* * *}$} & {$[1.700]^{* * *}$} & {$[0.952]$} & [1.142] & [1.159] \\
\hline \multirow{2}{*}{ L5. Dist. to front. $\mathrm{x}$ dem. polityIV } & 0.008 & & & -0.022 & & & -0.056 & & \\
\hline & {$[0.024]$} & & & {$[0.023]$} & & & {$[0.018]^{* * *}$} & & \\
\hline \multirow[t]{2}{*}{ L5. Dem. polityIV } & 0.001 & & & 0.005 & & & 0.004 & & \\
\hline & {$[0.004]$} & & & {$[0.004]$} & & & {$[0.003]$} & & \\
\hline \multirow[t]{2}{*}{ L5. Dist. to front. x Polit. rights } & & -0.076 & & & -0.138 & & & -0.29 & \\
\hline & & {$[0.076]$} & & & {$[0.080]^{*}$} & & & {$[0.052]^{* * *}$} & \\
\hline \multirow[t]{2}{*}{ L5. Polit. rights } & & 0.006 & & & 0.01 & & & 0.039 & \\
\hline & & [0.014] & & & {$[0.014]$} & & & {$[0.010]^{* * *}$} & \\
\hline \multirow[t]{2}{*}{ L5. Dist. to front. x Civil liberty } & & & -0.128 & & & -0.21 & & & -0.249 \\
\hline & & & {$[0.087]$} & & & {$[0.093]^{* *}$} & & & {$[0.063]^{* * *}$} \\
\hline \multirow[t]{2}{*}{ L5. Civil liberty } & & & 0.003 & & & 0.019 & & & 0.04 \\
\hline & & & {$[0.015]$} & & & {$[0.016]$} & & & {$[0.011]^{* * *}$} \\
\hline \multirow[t]{2}{*}{ L5. Dist. to front. x real GDP p.c. } & -0.192 & -0.269 & -0.256 & -0.063 & -0.047 & -0.007 & -0.155 & -0.1 & -0.104 \\
\hline & {$[0.147]$} & {$[0.179]$} & {$[0.175]$} & {$[0.153]$} & [0.192] & {$[0.190]$} & {$[0.110]$} & {$[0.130]$} & {$[0.128]$} \\
\hline \multirow[t]{2}{*}{ L5. Real GDP p.c. } & -0.148 & -0.298 & -0.29 & 0.087 & -0.11 & -0.117 & -0.218 & -0.223 & -0.237 \\
\hline & {$[0.061]^{* *}$} & {$[0.070]^{* * *}$} & {$[0.070]^{* * *}$} & {$[0.059]$} & {$[0.069]$} & {$[0.069]^{*}$} & {$[0.044]^{* * *}$} & {$[0.051]^{* * *}$} & {$[0.050]^{* * *}$} \\
\hline Observations & 8110 & 7449 & 7449 & 8427 & 7649 & 7649 & 8607 & 7893 & 7893 \\
\hline Number of industry-country & 2205 & 2295 & 2295 & 2250 & 2318 & 2318 & 2257 & 2368 & 2368 \\
\hline \multirow[t]{3}{*}{ R-squared } & 0.34 & 0.31 & 0.31 & 0.33 & 0.3 & 0.3 & 0.09 & 0.07 & 0.06 \\
\hline & 10-year & 10-year & 10-year & 10-year & 10-year & 10-year & 10-year & 10 -year & 10-year \\
\hline & $\begin{array}{l}\text { Output } \\
\text { growth }\end{array}$ & $\begin{array}{l}\text { Output } \\
\text { growth }\end{array}$ & $\begin{array}{l}\text { Output } \\
\text { growth }\end{array}$ & $\begin{array}{l}\text { VA } \\
\text { growth }\end{array}$ & $\begin{array}{l}\text { VA } \\
\text { growth }\end{array}$ & $\begin{array}{l}\text { VA } \\
\text { growth }\end{array}$ & $\begin{array}{l}\text { Emp. } \\
\text { growth }\end{array}$ & $\begin{array}{l}\text { Emp. } \\
\text { growth }\end{array}$ & $\begin{array}{l}\text { Emp. } \\
\text { growth }\end{array}$ \\
\hline 1975-1985-1995 & rate & rate & rate & rate & rate & rate & rate & rate & rate \\
\hline \multirow[t]{2}{*}{ L10. Distance to frontier in VA/Emp } & 13.985 & 15.496 & 16.527 & 10.689 & 11.224 & 12.987 & 1.274 & -3.171 & -1.676 \\
\hline & {$[2.278]^{* * *}$} & {$[3.945]^{* * *}$} & {$[4.212]^{* * *}$} & {$[2.503]^{* * *}$} & {$[5.250]^{* *}$} & {$[5.384]^{* *}$} & {$[1.713]$} & {$[2.997]$} & {$[3.181]$} \\
\hline \multirow[t]{2}{*}{ L10. Dist. to front. $x$ dem. polityIV } & -0.04 & & & -0.066 & & & -0.035 & & \\
\hline & {$[0.057]$} & & & {$[0.053]$} & & & {$[0.044]$} & & \\
\hline \multirow[t]{2}{*}{ L10. Dem. polityIV } & 0.01 & & & 0.012 & & & 0.017 & & \\
\hline & {$[0.010]$} & & & {$[0.009]$} & & & {$[0.007]^{* *}$} & & \\
\hline \multirow[t]{2}{*}{ L10. Dist. to front. x Polit. rights } & & -0.58 & & & -0.447 & & & -0.469 & \\
\hline & & {$[0.216]^{* * *}$} & & & {$[0.223]^{* *}$} & & & {$[0.157]^{* * *}$} & \\
\hline \multirow[t]{2}{*}{ L10. Polit. rights } & & 0.105 & & & 0.046 & & & 0.095 & \\
\hline & & {$[0.040]^{* * *}$} & & & {$[0.042]$} & & & {$[0.027]^{* * *}$} & \\
\hline \multirow[t]{2}{*}{ L10. Dist. to front. x Civil liberty } & & & -0.387 & & & -0.334 & & & -0.576 \\
\hline & & & {$[0.266]$} & & & {$[0.266]$} & & & {$[0.198]^{* * *}$} \\
\hline \multirow[t]{2}{*}{ L10. Civil liberty } & & & 0.157 & & & 0.172 & & & 0.123 \\
\hline & & & {$[0.040]^{* * *}$} & & & {$[0.041]^{* * *}$} & & & {$[0.029]^{* * *}$} \\
\hline \multirow[t]{2}{*}{ L10. Dist. to front. $x$ real GDP p.c. } & -1.319 & -1.073 & -1.318 & -0.655 & -0.362 & -0.654 & -0.309 & 0.529 & 0.395 \\
\hline & {$[0.277] * * *$} & {$[0.450]^{* *}$} & {$[0.441]^{* * *}$} & {$[0.296]^{* *}$} & {$[0.600]$} & {$[0.580]$} & {$[0.209]$} & {$[0.339]$} & {$[0.335]$} \\
\hline \multirow[t]{2}{*}{ L10. Real GDP p.c. } & 0.183 & 0.218 & 0.219 & 0.305 & 0.399 & 0.413 & -0.422 & -0.523 & -0.5 \\
\hline & {$[0.147]$} & {$[0.214]$} & {$[0.216]$} & {$[0.139]^{* *}$} & {$[0.226]^{*}$} & {$[0.225]^{*}$} & {$[0.104]^{* * *}$} & {$[0.151]^{* * *}$} & {$[0.151]^{* * *}$} \\
\hline Observations & 3803 & 3045 & 3045 & 3900 & 3114 & 3114 & 3999 & 3238 & 3238 \\
\hline Number of industry-country & 1835 & 1812 & 1812 & 1864 & 1831 & 1831 & 1896 & 1868 & 1868 \\
\hline R-squared & 0.22 & 0.13 & 0.13 & 0.22 & 0.15 & 0.16 & 0.09 & 0.03 & 0.03 \\
\hline
\end{tabular}


Table 3: Differential effect of democracy depending on distance to frontier (cont.)

\begin{tabular}{|c|c|c|c|c|c|c|c|c|c|}
\hline & $\begin{array}{l}\text { F.E. SIC } \\
\text { country } \\
\text { year }\end{array}$ & $\begin{array}{l}\text { F.E. SIC } \\
\text { country } \\
\text { year }\end{array}$ & $\begin{array}{l}\text { F.E. SIC } \\
\text { country } \\
\text { year }\end{array}$ & $\begin{array}{l}\text { F.E. SIC } \\
\text { country } \\
\text { year }\end{array}$ & $\begin{array}{l}\text { F.E. SIC } \\
\text { country } \\
\text { year }\end{array}$ & $\begin{array}{l}\text { F.E. SIC } \\
\text { country } \\
\text { year }\end{array}$ & $\begin{array}{l}\text { F.E. SIC } \\
\text { country } \\
\text { year }\end{array}$ & $\begin{array}{l}\text { F.E. SIC } \\
\text { country } \\
\text { year }\end{array}$ & $\begin{array}{l}\text { F.E. SIC } \\
\text { country } \\
\text { year }\end{array}$ \\
\hline & 10-year & 10-year & 10-year & 10-year & 10-year & 10-year & 10-year & 10-year & 10-year \\
\hline 1980-1990-2000 & $\begin{array}{l}\text { Output } \\
\text { growth } \\
\text { rate }\end{array}$ & $\begin{array}{l}\text { Output } \\
\text { growth } \\
\text { rate }\end{array}$ & $\begin{array}{l}\text { Output } \\
\text { growth } \\
\text { rate }\end{array}$ & $\begin{array}{l}\mathrm{VA} \\
\text { growth } \\
\text { rate }\end{array}$ & $\begin{array}{l}\text { VA } \\
\text { growth } \\
\text { rate }\end{array}$ & $\begin{array}{l}\mathrm{VA} \\
\text { growth } \\
\text { rate }\end{array}$ & $\begin{array}{l}\text { Emp. } \\
\text { growth } \\
\text { rate }\end{array}$ & $\begin{array}{l}\text { Emp. } \\
\text { growth } \\
\text { rate }\end{array}$ & $\begin{array}{l}\text { Emp. } \\
\text { growth } \\
\text { rate }\end{array}$ \\
\hline \multirow[t]{2}{*}{ L10. Distance to frontier in VA/Emp } & 6.672 & 11.612 & 11.296 & 4.619 & 13.327 & 13.666 & 8.025 & 15.233 & 15.414 \\
\hline & {$[2.682]^{* *}$} & {$[4.183]^{* * *}$} & {$[4.117]^{* * *}$} & [2.955] & {$[4.260]^{* * *}$} & {$[4.234]^{* * *}$} & {$[2.196]^{* * *}$} & {$[3.648]^{* * *}$} & {$[3.612]^{* * *}$} \\
\hline \multirow[t]{2}{*}{ L10. Dist. to front. $x$ dem. polityIV } & 0.158 & & & 0.147 & & & 0.062 & & \\
\hline & {$[0.047]^{* * *}$} & & & {$[0.046]^{* * *}$} & & & [0.039] & & \\
\hline \multirow[t]{2}{*}{ L10. Dem. polityIV } & -0.027 & & & -0.033 & & & -0.021 & & \\
\hline & {$[0.006]^{* * *}$} & & & {$[0.007]^{* * *}$} & & & {$[0.005]^{* * *}$} & & \\
\hline \multirow[t]{2}{*}{ L10. Dist. to front. $x$ Polit. rights } & & -0.676 & & & -0.763 & & & -0.683 & \\
\hline & & {$[0.201]^{* * *}$} & & & {$[0.194]^{* * *}$} & & & {$[0.161]^{* * *}$} & \\
\hline \multirow[t]{2}{*}{ L10. Polit. rights } & & 0.064 & & & 0.067 & & & 0.004 & \\
\hline & & {$[0.023]^{* * *}$} & & & {$[0.024]^{* * *}$} & & & {$[0.022]$} & \\
\hline \multirow[t]{2}{*}{ L10. Dist. to front. $\mathrm{x}$ Civil liberty } & & & -0.697 & & & -0.852 & & & -0.841 \\
\hline & & & {$[0.214]^{* * *}$} & & & {$[0.214]^{* * *}$} & & & {$[0.166]^{* * *}$} \\
\hline \multirow[t]{2}{*}{ L10. Civil liberty } & & & 0.115 & & & 0.1 & & & 0.023 \\
\hline & & & {$[0.033]^{* * *}$} & & & {$[0.037]^{* * *}$} & & & {$[0.026]$} \\
\hline \multirow[t]{2}{*}{ L10. Dist. to front. $x$ real GDP p.c. } & -0.483 & -0.444 & -0.411 & -0.121 & -0.427 & -0.414 & -1.083 & -1.263 & -1.197 \\
\hline & {$[0.306]$} & {$[0.428]$} & {$[0.414]$} & {$[0.334]$} & {$[0.451]$} & {$[0.432]$} & {$[0.246]^{* * *}$} & {$[0.395]^{* * *}$} & {$[0.378]^{* * *}$} \\
\hline \multirow[t]{2}{*}{ L10. Real GDP p.c. } & -0.542 & -0.89 & -1.071 & -0.511 & -0.83 & -0.959 & -0.254 & 0.151 & 0.099 \\
\hline & {$[0.127]^{* * *}$} & {$[0.179]^{* * *}$} & {$[0.173]^{* * *}$} & {$[0.140]^{* * *}$} & {$[0.180]^{* * *}$} & {$[0.172]^{* * *}$} & {$[0.111]^{* *}$} & {$[0.142]$} & {$[0.141]$} \\
\hline Observations & 3546 & 2499 & 2499 & 3662 & 2546 & 2546 & 3729 & 2638 & 2638 \\
\hline Number of industry-country & 1737 & 1599 & 1599 & 1784 & 1634 & 1634 & 1782 & 1619 & 1619 \\
\hline R-squared & 0.47 & 0.22 & 0.22 & 0.4 & 0.25 & 0.25 & 0.18 & 0.08 & 0.09 \\
\hline \multicolumn{10}{|l|}{ Clustered standard errors in brackets } \\
\hline significant at $10 \%$; ** significant at 5 & **. & cant at $1 \%$ & & & & & & & \\
\hline
\end{tabular}


Table 4: Growth, Democracy, and Actual entry

\begin{tabular}{|c|c|c|c|c|c|c|c|c|c|}
\hline & $\begin{array}{l}\text { F.E. SIC } \\
\text { country } \\
\text { year }\end{array}$ & $\begin{array}{l}\text { F.E. SIC } \\
\text { country } \\
\text { year }\end{array}$ & $\begin{array}{l}\text { F.E. SIC } \\
\text { country } \\
\text { year }\end{array}$ & $\begin{array}{l}\text { F.E. SIC } \\
\text { country } \\
\text { year }\end{array}$ & $\begin{array}{l}\text { F.E. SIC } \\
\text { country } \\
\text { year }\end{array}$ & $\begin{array}{l}\text { F.E. SIC } \\
\text { country } \\
\text { year }\end{array}$ & $\begin{array}{l}\text { F.E. SIC } \\
\text { country } \\
\text { year }\end{array}$ & $\begin{array}{l}\text { F.E. SIC } \\
\text { country } \\
\text { year }\end{array}$ & $\begin{array}{l}\text { F.E. SIC } \\
\text { country } \\
\text { year }\end{array}$ \\
\hline 1985-90, 1990-95, 1995-2000 & $\begin{array}{l}\text { Output } \\
\text { growth } \\
\text { rate }\end{array}$ & $\begin{array}{l}\text { Output } \\
\text { growth } \\
\text { rate }\end{array}$ & $\begin{array}{l}\text { Output } \\
\text { growth } \\
\text { rate }\end{array}$ & $\begin{array}{l}\text { Value } \\
\text { added } \\
\text { growth }\end{array}$ & $\begin{array}{l}\text { Value } \\
\text { added } \\
\text { growth }\end{array}$ & $\begin{array}{l}\text { Value } \\
\text { added } \\
\text { growth }\end{array}$ & $\begin{array}{l}\text { 5-year } \\
\text { Employm } \\
\text { ent }\end{array}$ & $\begin{array}{l}\text { 5-year } \\
\text { Employm } \\
\text { ent }\end{array}$ & $\begin{array}{l}\text { 5-year } \\
\text { Employm } \\
\text { ent }\end{array}$ \\
\hline L5. Distance to frontier in VA/Emp & $\begin{array}{l}-16.168 \\
{[9.651]^{*}}\end{array}$ & $\begin{array}{l}-10.385 \\
{[7.660]}\end{array}$ & $\begin{array}{l}-0.197 \\
{[8.171]}\end{array}$ & $\begin{array}{l}-15.656 \\
{[10.027]}\end{array}$ & $\begin{array}{l}-11.037 \\
{[9.887]}\end{array}$ & $\begin{array}{l}0.732 \\
{[9.496]}\end{array}$ & $\begin{array}{l}-0.187 \\
{[7.299]}\end{array}$ & $\begin{array}{l}2.102 \\
{[5.304]}\end{array}$ & $\begin{array}{l}3.607 \\
{[5.394]}\end{array}$ \\
\hline L5. Dist. to front. x 5-yr No. Esta.growth & $\begin{array}{l}-0.296 \\
{[0.549]}\end{array}$ & $\begin{array}{l}-0.372 \\
{[0.514]}\end{array}$ & $\begin{array}{l}-0.448 \\
{[0.526]}\end{array}$ & $\begin{array}{l}0.236 \\
{[0.450]}\end{array}$ & $\begin{array}{l}0.13 \\
{[0.462]}\end{array}$ & $\begin{array}{l}0.163 \\
{[0.451]}\end{array}$ & $\begin{array}{l}-0.192 \\
{[0.465]}\end{array}$ & $\begin{array}{l}-0.381 \\
{[0.453]}\end{array}$ & $\begin{array}{l}-0.33 \\
{[0.480]}\end{array}$ \\
\hline L5. 5-year No. Establ. growth rate & $\begin{array}{l}-0.058 \\
{[0.081]}\end{array}$ & $\begin{array}{l}-0.066 \\
{[0.078]}\end{array}$ & $\begin{array}{l}-0.055 \\
{[0.080]}\end{array}$ & $\begin{array}{l}-0.143 \\
{[0.045]^{* * *}}\end{array}$ & $\begin{array}{l}-0.165 \\
{[0.045]^{* * *}}\end{array}$ & $\begin{array}{l}-0.176 \\
{[0.046]^{* * *}}\end{array}$ & $\begin{array}{l}-0.055 \\
{[0.053]}\end{array}$ & $\begin{array}{l}-0.047 \\
{[0.051]}\end{array}$ & $\begin{array}{l}-0.046 \\
{[0.054]}\end{array}$ \\
\hline L5. Dist. to front. $x$ dem. polityIV & $\begin{array}{l}-0.368 \\
{[0.205]^{*}}\end{array}$ & & & $\begin{array}{l}-0.36 \\
{[0.200]^{*}}\end{array}$ & & & $\begin{array}{l}-0.208 \\
{[0.150]}\end{array}$ & & \\
\hline L5. Dem. polityIV & $\begin{array}{l}0.105 \\
{[0.033]^{* * *}}\end{array}$ & & & $\begin{array}{l}0.137 \\
{[0.030]^{* * *}}\end{array}$ & & & $\begin{array}{l}0 \\
{[0.028]}\end{array}$ & & \\
\hline L5. Dist. to front. $x$ Polit. rights & & $\begin{array}{l}0.497 \\
{[0.283]^{*}}\end{array}$ & & & $\begin{array}{l}0.611 \\
{[0.274]^{* *}}\end{array}$ & & & $\begin{array}{l}0.062 \\
{[0.149]}\end{array}$ & \\
\hline L5. Polit. rights & & $\begin{array}{l}-0.111 \\
{[0.070]}\end{array}$ & & & $\begin{array}{l}-0.119 \\
{[0.066]^{*}}\end{array}$ & & & $\begin{array}{l}0.05 \\
{[0.047]}\end{array}$ & \\
\hline L5. Dist. to front. x Civil liberty & & & $\begin{array}{l}-0.453 \\
{[0.340]}\end{array}$ & & & $\begin{array}{l}-0.394 \\
{[0.368]}\end{array}$ & & & $\begin{array}{l}-0.206 \\
{[0.254]}\end{array}$ \\
\hline L5. Civil liberty & & & $\begin{array}{l}-0.074 \\
{[0.048]}\end{array}$ & & & $\begin{array}{l}-0.1 \\
{[0.049]^{* *}}\end{array}$ & & & $\begin{array}{l}0.022 \\
{[0.032]}\end{array}$ \\
\hline L5. Dist. to front. x Real GDP p.c. & $\begin{array}{l}2.577 \\
{[1.115]^{* *}}\end{array}$ & $\begin{array}{l}1.749 \\
{[0.867]^{* *}}\end{array}$ & $\begin{array}{l}1.086 \\
{[0.913]}\end{array}$ & $\begin{array}{l}2.83 \\
{[1.164]^{* *}}\end{array}$ & $\begin{array}{l}2.102 \\
{[1.088]^{*}}\end{array}$ & $\begin{array}{l}1.288 \\
{[1.044]}\end{array}$ & $\begin{array}{l}0.103 \\
{[0.883]}\end{array}$ & $\begin{array}{l}-0.24 \\
{[0.620]}\end{array}$ & $\begin{array}{l}-0.266 \\
{[0.624]}\end{array}$ \\
\hline L5. Real GDP p.c. & $\begin{array}{l}-1.673 \\
{[0.347]^{* * *}}\end{array}$ & $\begin{array}{l}-1.478 \\
{[0.224]^{* * *}}\end{array}$ & $\begin{array}{l}-1.731 \\
{[0.217]^{* * *}}\end{array}$ & $\begin{array}{l}-1.791 \\
{[0.309]^{* * *}}\end{array}$ & $\begin{array}{l}-1.777 \\
{[0.225]^{* * *}}\end{array}$ & $\begin{array}{l}-2.01 \\
{[0.219]^{* * *}}\end{array}$ & $\begin{array}{l}-0.864 \\
{[0.201]^{* * *}}\end{array}$ & $\begin{array}{l}-0.575 \\
{[0.158]^{* * *}}\end{array}$ & $\begin{array}{l}-0.624 \\
{[0.164]^{* * *}}\end{array}$ \\
\hline Observations & 1694 & 1789 & 1789 & 1742 & 1835 & 1835 & 1819 & 1910 & 1910 \\
\hline Number of industry-country & 1117 & 1161 & 1161 & 1145 & 1187 & 1187 & 1184 & 1228 & 1228 \\
\hline R-squared & 0.31 & 0.33 & 0.34 & 0.37 & 0.4 & 0.41 & 0.12 & 0.1 & 0.1 \\
\hline
\end{tabular}


Table 4: Growth, Democracy, and Actual entry (Cont.)

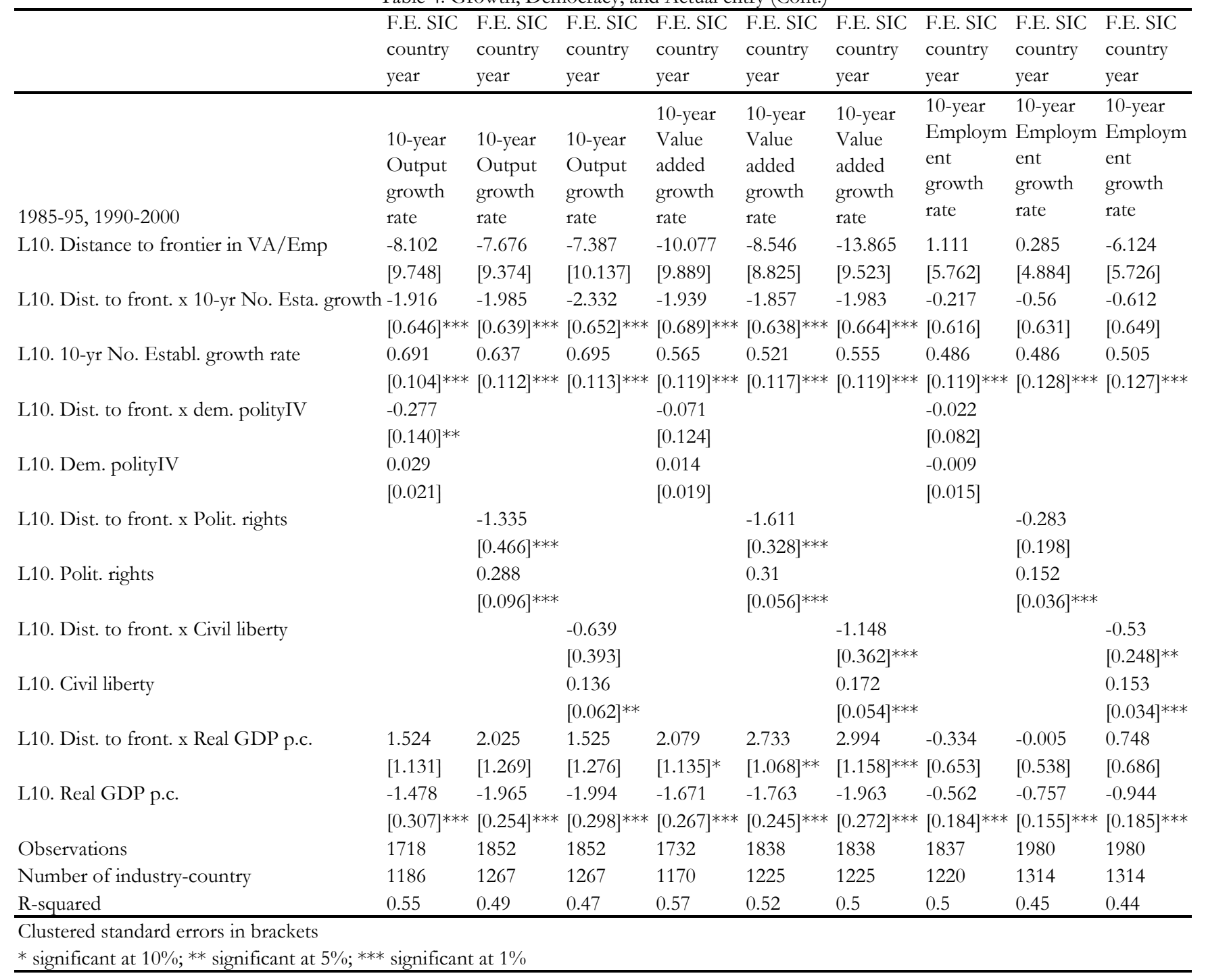


Table A1: Summary Statistics by Year

\begin{tabular}{|c|c|c|c|c|c|c|c|c|c|c|}
\hline Year & 1975 & 1975 & 1975 & 1975 & 1975 & 1980 & 1980 & 1980 & 1980 & 1980 \\
\hline Variable & Obs & Mean & St.dev. & Min & Max & Obs & Mean & St.dev. & Min & Max \\
\hline $\log Y$ & 2249 & 19.16 & 2.75 & 8.15 & 26.73 & 2348 & 19.60 & 2.73 & 9.04 & 26.76 \\
\hline $\log V A$ & 2272 & 18.09 & 2.63 & 10.26 & 25.66 & 2269 & 18.52 & 2.63 & 10.50 & 25.97 \\
\hline $\log E m p$ & 2494 & 8.45 & 2.43 & 0.00 & 15.79 & 2576 & 8.63 & 2.41 & 0.00 & 15.79 \\
\hline logEsta & 0 & & & & & 0 & & & & \\
\hline $\operatorname{dlog} \mathrm{Y}$ & 2176 & 0.04 & 0.32 & -3.54 & 4.25 & 2184 & 0.06 & 0.34 & -3.58 & 7.79 \\
\hline$d \log V A$ & 2238 & 0.03 & 0.33 & -3.18 & 4.13 & 2133 & 0.04 & 0.35 & -3.19 & 7.96 \\
\hline dlogEmp & 2428 & 0.04 & 0.26 & -2.85 & 3.76 & 2469 & 0.02 & 0.26 & -2.84 & 6.58 \\
\hline dlogEsta & 0 & & & & & 0 & & & & \\
\hline $\mathrm{d} 5 \log \mathrm{Y}$ & 1869 & 0.61 & 0.58 & -2.35 & 5.39 & 2054 & 0.41 & 0.57 & -3.48 & 4.44 \\
\hline $\mathrm{d} 5 \log \mathrm{VA}$ & 2074 & 0.57 & 0.60 & -2.70 & 4.48 & 2101 & 0.39 & 0.60 & -3.21 & 4.15 \\
\hline $\mathrm{d} 5 \log \mathrm{Emp}$ & 2191 & 0.26 & 0.47 & -1.61 & 3.24 & 2342 & 0.16 & 0.50 & -3.67 & 6.92 \\
\hline d5logEsta & 0 & & & & & 0 & & & & \\
\hline $\mathrm{d} 10 \log \mathrm{Y}$ & 1429 & 0.93 & 0.78 & -2.42 & 5.59 & 1812 & 0.98 & 0.81 & -3.49 & 6.99 \\
\hline $\mathrm{d} 10 \log \mathrm{VA}$ & 1475 & 0.90 & 0.77 & -1.67 & 5.71 & 1971 & 0.91 & 0.84 & -3.64 & 6.51 \\
\hline d10logEmp & 1584 & 0.44 & 0.63 & -2.45 & 4.38 & 2143 & 0.41 & 0.70 & -3.64 & 6.45 \\
\hline d10logEsta & 0 & & & & & 0 & & & & \\
\hline distfront & 2171 & 0.15 & 0.08 & 0.00 & 0.45 & 2159 & 0.15 & 0.08 & 0.00 & 0.49 \\
\hline db_proc_99 & 1911 & 10.19 & 4.51 & 2.00 & 21.00 & 1969 & 10.22 & 4.45 & 2.00 & 21.00 \\
\hline polityIV & 2837 & -0.91 & 7.83 & -10.00 & 10.00 & 2836 & -0.33 & 7.98 & -10.00 & 10.00 \\
\hline pr & 3168 & 3.64 & 2.24 & 1.00 & 7.00 & 3262 & 3.96 & 2.20 & 1.00 & 7.00 \\
\hline $\mathrm{cl}$ & 3168 & 3.98 & 1.94 & 1.00 & 7.00 & 3262 & 3.95 & 1.96 & 1.00 & 7.00 \\
\hline Year & 1985 & 1985 & 1985 & 1985 & 1985 & 1990 & 1990 & 1990 & 1990 & 1990 \\
\hline Variable & Obs & Mean & St.dev. & Min & Max & Obs & Mean & St.dev. & Min & Max \\
\hline $\log Y$ & 2249 & 19.51 & 2.69 & 9.31 & 26.85 & 2286 & 19.73 & 2.79 & 10.20 & 26.88 \\
\hline $\log V A$ & 2067 & 18.51 & 2.54 & 10.34 & 25.94 & 2124 & 18.89 & 2.62 & 9.29 & 25.96 \\
\hline $\log E m p$ & 2387 & 8.73 & 2.44 & 0.00 & 15.80 & 2441 & 8.88 & 2.31 & 0.00 & 16.11 \\
\hline logEsta & 2069 & 4.37 & 2.24 & 0.00 & 11.02 & 2202 & 4.38 & 2.25 & 0.00 & 10.97 \\
\hline $\operatorname{dlog} Y$ & 2179 & -0.02 & 0.32 & -2.50 & 4.78 & 2048 & 0.00 & 0.43 & -5.83 & 3.49 \\
\hline dlogVA & 1992 & -0.04 & 0.36 & -2.40 & 4.86 & 1941 & 0.03 & 0.43 & -6.08 & 4.46 \\
\hline dlogEmp & 2309 & 0.01 & 0.21 & -3.89 & 3.82 & 2159 & 0.02 & 0.26 & -3.21 & 2.99 \\
\hline dlogEsta & 1892 & 0.03 & 0.21 & -1.61 & 1.72 & 1912 & 0.09 & 0.42 & -4.62 & 3.76 \\
\hline $\mathrm{d} 5 \log \mathrm{Y}$ & 2008 & -0.26 & 0.58 & -4.94 & 4.30 & 1787 & 0.32 & 0.63 & -7.91 & 4.47 \\
\hline $\mathrm{d} 5 \log \mathrm{VA}$ & 1868 & -0.31 & 0.63 & -5.15 & 4.52 & 1701 & 0.34 & 0.66 & -7.12 & 3.35 \\
\hline $\mathrm{d} 5 \log E \mathrm{mp}$ & 2181 & -0.01 & 0.43 & -3.60 & 4.91 & 1881 & 0.09 & 0.45 & -6.38 & 3.93 \\
\hline d5 logEsta & 0 & & & & & 1576 & 0.23 & 0.67 & -4.31 & 4.27 \\
\hline $\mathrm{d} 10 \log \mathrm{Y}$ & 1875 & 0.15 & 0.77 & -4.11 & 4.68 & 1736 & 0.07 & 0.76 & -4.62 & 7.27 \\
\hline $\mathrm{d} 10 \log \mathrm{VA}$ & 1835 & 0.11 & 0.79 & -2.78 & 3.85 & 1717 & 0.05 & 0.82 & -6.09 & 7.39 \\
\hline d10logEmp & 2086 & 0.15 & 0.65 & -4.22 & 5.15 & 1871 & 0.07 & 0.61 & -4.97 & 7.76 \\
\hline d10logEsta & 0 & & & & & 0 & & & & \\
\hline distfront & 2100 & 0.15 & 0.08 & 0.00 & 0.47 & 1953 & 0.16 & 0.09 & 0.00 & 0.53 \\
\hline db_proc_99 & 1989 & 10.20 & 4.43 & 2.00 & 21.00 & 2133 & 10.19 & 4.33 & 2.00 & 21.00 \\
\hline polityIV & 2861 & 0.37 & 7.93 & -10.00 & 10.00 & 2806 & 2.45 & 7.41 & -10.00 & 10.00 \\
\hline
\end{tabular}




\begin{tabular}{lllllllllll}
$\mathrm{pr}$ & 3287 & 4.12 & 2.23 & 1.00 & 7.00 & 3151 & 4.46 & 2.19 & 1.00 & 7.00 \\
$\mathrm{cl}$ & 3287 & 3.90 & 2.05 & 1.00 & 7.00 & 3151 & 4.53 & 1.86 & 1.00 & 7.00 \\
\hline
\end{tabular}

Table A1: Summary Statistics by Year (Cont.)

\begin{tabular}{|c|c|c|c|c|c|c|c|c|c|c|}
\hline Year & 1995 & 1995 & 1995 & 1995 & 1995 & 2000 & 2000 & 2000 & 2000 & 2000 \\
\hline Variable & Obs & Mean & St.dev. & Min & Max & Obs & Mean & St.dev. & Min & Max \\
\hline $\log Y$ & 2289 & 19.31 & 2.99 & 8.35 & 27.00 & 1649 & 19.71 & 3.05 & 6.68 & 27.12 \\
\hline $\log V A$ & 1982 & 18.69 & 2.85 & 8.00 & 26.04 & 1405 & 19.16 & 2.71 & 8.70 & 26.20 \\
\hline $\log E m p$ & 2408 & 8.68 & 2.39 & 0.00 & 15.77 & 1780 & 8.90 & 2.38 & 0.00 & 15.41 \\
\hline logEsta & 2225 & 4.40 & 2.50 & 0.00 & 11.38 & 1695 & 5.05 & 2.44 & 0.00 & 11.47 \\
\hline $\mathrm{d} \log \mathrm{Y}$ & 2171 & 0.08 & 0.49 & -7.69 & 6.70 & 1579 & 0.03 & 0.31 & -2.31 & 2.31 \\
\hline dlogVA & 1877 & 0.07 & 0.51 & -6.60 & 5.68 & 1312 & -0.01 & 0.27 & -1.92 & 1.73 \\
\hline dlogEmp & 2280 & 0.00 & 0.34 & -4.12 & 4.20 & 1674 & 0.00 & 0.20 & -2.39 & 1.78 \\
\hline dlogEsta & 2109 & 0.10 & 0.48 & -2.69 & 3.84 & 1621 & 0.05 & 0.36 & -3.76 & 2.68 \\
\hline d5 $\log Y$ & 1709 & 0.06 & 0.91 & -5.92 & 5.09 & 1495 & -0.07 & 0.75 & -7.10 & 6.02 \\
\hline d5 $\log V A$ & 1654 & 0.04 & 0.80 & -6.47 & 4.08 & 1246 & -0.07 & 0.63 & -4.64 & 3.94 \\
\hline $\mathrm{d} 5 \log E \mathrm{mp}$ & 1944 & -0.11 & 0.68 & -5.89 & 4.30 & 1613 & -0.07 & 0.50 & -4.69 & 2.78 \\
\hline d5logEsta & 1673 & 0.33 & 0.97 & -4.23 & 4.87 & 1396 & 0.15 & 0.70 & -4.22 & 5.46 \\
\hline d10logY & 1546 & 0.43 & 1.03 & -10.86 & 5.31 & 1233 & 0.02 & 1.11 & -5.82 & 5.68 \\
\hline d10logVA & 1486 & 0.47 & 0.97 & -6.89 & 4.67 & 1126 & 0.05 & 0.83 & -4.87 & 5.29 \\
\hline d10logEmp & 1677 & 0.12 & 0.73 & -6.20 & 4.33 & 1417 & -0.14 & 0.78 & -5.37 & 3.43 \\
\hline d10logEsta & 1328 & 0.50 & 1.13 & -3.57 & 5.01 & 1289 & 0.53 & 1.11 & -4.25 & 5.23 \\
\hline distfront & 1969 & 0.18 & 0.10 & 0.00 & 0.82 & 1410 & 0.16 & 0.10 & 0.00 & 0.85 \\
\hline db_proc_99 & 2194 & 10.30 & 4.34 & 2.00 & 21.00 & 1954 & 10.17 & 4.39 & 2.00 & 21.00 \\
\hline polityIV & 3241 & 3.79 & 6.54 & -10.00 & 10.00 & 2542 & 4.96 & 6.07 & -10.00 & 10.00 \\
\hline pr & 3576 & 4.74 & 2.06 & 1.00 & 7.00 & 2729 & 5.11 & 2.06 & 1.00 & 7.00 \\
\hline $\mathrm{cl}$ & 3576 & 4.48 & 1.79 & 1.00 & 7.00 & 2729 & 4.87 & 1.64 & 1.00 & 7.00 \\
\hline
\end{tabular}


Table A2: Explaining the differential: Entry and democracy

\begin{tabular}{|c|c|c|c|c|c|c|c|c|}
\hline & $\begin{array}{l}\text { Procedure } \\
\text { s No. }\end{array}$ & $\begin{array}{l}\text { Procedure } \\
\text { s No. }\end{array}$ & $\begin{array}{l}\text { Procedure } \\
\text { s No. }\end{array}$ & $\begin{array}{l}\text { Procedure } \\
\text { s No. }\end{array}$ & $\begin{array}{l}\text { Procedure } \\
\text { s No. }\end{array}$ & $\begin{array}{l}\text { Procedure } \\
\text { s No. }\end{array}$ & $\begin{array}{l}\text { Procedure } \\
\text { s No. }\end{array}$ & $\begin{array}{l}\text { Procedure } \\
\text { s No. }\end{array}$ \\
\hline \multirow[t]{2}{*}{ GDP per capita, log } & -0.544 & -0.687 & -0.111 & -0.367 & -0.757 & -0.853 & -1.094 & -0.783 \\
\hline & {$[0.337]$} & {$[0.367]^{*}$} & {$[0.382]$} & {$[0.511]$} & {$[0.320]^{* *}$} & {$[0.338]^{* *}$} & {$[0.440]^{* *}$} & {$[0.383]^{* *}$} \\
\hline \multirow[t]{2}{*}{ executive de facto independence } & -0.853 & & & & & & & \\
\hline & {$[0.270]^{* * *}$} & & & & & & & \\
\hline \multirow[t]{2}{*}{ constraints on executive power } & & -0.658 & & & & & & \\
\hline & & {$[0.290]^{* *}$} & & & & & & \\
\hline \multirow[t]{2}{*}{ effectiveness of legislature } & & & -2.553 & & & & & \\
\hline & & & {$[0.661]^{* * *}$} & & & & & \\
\hline \multirow[t]{2}{*}{ government effectiveness } & & & & -1.88 & & & & \\
\hline & & & & {$[0.933]^{* *}$} & & & & \\
\hline \multirow[t]{2}{*}{ competition in the legisl. nominating process } & & & & & -2.051 & & & \\
\hline & & & & & {$[0.963]^{* *}$} & & & \\
\hline \multirow[t]{2}{*}{ autocracy } & & & & & & 0.322 & & \\
\hline & & & & & & {$[0.185]^{*}$} & & \\
\hline \multirow[t]{2}{*}{ political rights average 1972-99 } & & & & & & & -0.655 & \\
\hline & & & & & & & {$[2.263]$} & \\
\hline \multirow[t]{2}{*}{ civil rights average 1972-99 } & & & & & & & & -4.171 \\
\hline & & & & & & & & {$[2.362]^{*}$} \\
\hline Observations & 84 & 84 & 73 & 85 & 73 & 84 & 84 & 84 \\
\hline $\mathrm{R}$-squared & 0.26 & 0.24 & 0.3 & 0.25 & 0.22 & 0.22 & 0.2 & 0.23 \\
\hline \multicolumn{9}{|l|}{ Robust standard errors in brackets } \\
\hline$*$ significant at $10 \% ; * *$ significant at $5 \%$;*** & nnificant at 1 & & & & & & & \\
\hline
\end{tabular}

